\title{
Commitment and impersonation A reputation-based theory of principled behavior
}

\author{
Manvir Singh* \\ Institute for Advanced Study in Toulouse \\ Moshe Hoffman \\ Department of Economics, Harvard University \\ Media Lab, Massachusetts Institute of Technology
}

13 January 2021

* All correspondence should be sent to: Manvir Singh, Institute for Advanced Study in Toulouse, 1 Esplanade de’l Université, 31080 Toulouse cedex 6, France. Email: manvir.manvir@gmail.com

\begin{abstract}
Principled behavior seems to defy evolutionary logic. Principled people consistently abide by their principles, ignore tradeoffs or compromises, and pursue the principles for transcendental reasons, such as that they are "right", decreed by God, or part of an eternal debt to the emperor. Here, we explain principled behavior as a combination of what we call "committed agents" and "impersonators". Committed agents are individuals whose extreme psychology compels them to never deviate from a maxim and who are especially trustworthy for it. Imitators non-consciously masquerade as committed agents to garner trust. Given that observers can only determine whether a person is genuinely committed on the basis of their behavior, impersonators must appear to never deviate from the maxim, never think about deviating, pursue the maxim for the reason motivating committed agents, and justify ambiguous or compromising decision as conforming to the principle. We use this account to explain key features of principled behavior as well as seemingly unrelated phenomena, including cognitive dissonance, foot-in-the-door effects, moral licensing, sacred values, the expanding moral circle, and beliefs in supernatural punishment. Principled behavior consists of the behavior of rare extreme individuals and strategic attempts by others to pass as them.
\end{abstract}

Keywords: cooperation; evolution; game theory; morality; principles; reputation 


\section{COMMITMENT AND IMPERSONATION}

\section{The puzzle of principled behavior}

Here are some reasons the Vegan Society lists for becoming a vegan (The Vegan Society, 2020):

- "Avoiding animal products is one of the most obvious ways you can take a stand against animal cruelty and animal exploitation everywhere."

- "One of the most effective things an individual can do to lower their carbon footprint is to avoid all animal products."

- "Avoiding animal products is...the simplest way to take a stand against inefficient food systems which disproportionately affect the poorest people all over the world."

This is strange. Humans are evolved organisms (Darwin, 1871). Our minds are designed by natural selection to maximize currencies like sex, friends, and material resources (Barrett, 2015). From an evolutionary standpoint, an effective persuasion campaign should bring up points like, "A vegan diet makes you more attractive," or "Vegan food is cheaper than non-vegan food," or "Vegans have more friends and higher prestige than their non-vegan rivals." Yet, instead, the Vegan Society points out that becoming a vegan allows you to reduce suffering, protect the environment, and alleviate poverty. Who cares about suffering, carbon, and poverty when there's sex, food, and reputation to acquire?

Of course, many people care. They care enough about ending suffering that they donate to animal shelters and avoid buying products tested on animals (Lingel, 2018). They care enough about the environment that they buy hybrid vehicles and abandon air travel, even if it means spending weeks on a train (Griskevicius et al., 2010; Saner, 2019). And they care enough about alleviating poverty that they volunteer at food kitchens and campaign for legislative change (Kaufmann, 2013).

People abide by other values, too. They claim to never betray, never eat cow, never monetize love, and never damage a flag (Harris, 1978; A. P. McGraw et al., 2016; Wood, Jr., 1989). They claim to protect their chief, fight for the holy land, die for the emperor, fulfill their warrior duty, commit absolutely to a political position, and respond to any act of aggression with vicious retribution, even when it means death (Benedict, 1947; Boehm, 1984; Dumper, 2002; Easwaran, 2007; Erdland, 1961; Marietta, 2008).

People who act according to moral and social principles such as these tend to exhibit a suite of behaviors. They consistently abide by the principle (Beaman et al., 1983; Gawronski, 2012; Guadagno \& Cialdini, 2010; Stone \& Fernandez, 2008b). They refuse to consider costs, trade-offs, or compromises (Ginges et al., 2007; Tetlock, 2003). They prioritize the principle far beyond its instrumental value (Ginges \& Atran, 2015; Posner, 1998; Roth, 2007; Sunstein, 1994; Tetlock, 2000). And they maintain (and feel) that they act according to the principle for a transcendental reason - such as because the act is honorable, virtuous, "right", one's eternal duty, or what a supernatural entity demands-rather than for alternative material incentives (Stanford, 2018). These behaviors together constitute what we call principled behavior.

Principled behavior seems to violate basic maxims about human psychology: that we are self-interested and strategic. Our behavior produced by cognitive mechanisms designed to maximize reproductive success and respond to costs and benefits (Barrett, 2015; Pinker, 1997). Whether we help someone, for instance, depends on how related we are to them (Burnstein et al., 1994; Krupp et al., 2008), whether they've helped us in the past (Gurven, 2004; Trivers, 1971), how sexually attractive they are (Maestripieri et al., 2017), how attractive they are as a 


\section{COMMITMENT AND IMPERSONATION}

social partner (Eisenbruch et al., 2016; Pisor \& Gurven, 2018), whether other people are watching (Kraft-Todd et al., 2015; Yoeli et al., 2013), and whether we think they're responsible for their need (Greitemeyer, 2010; Rudolph et al., 2004), among many other factors. That we should abide by some value consistently and without considering the payoffs defies the adaptive plasticity of human behavior (see, e.g., Silk, 2003).

Principled behavior is further puzzling because of its variability. For one, principled behavior varies across communities: People in different places and time periods abide by different principles. Many contemporary Westerners claim universalist moral principles, such as "do not harm another person" and "treat other people fairly" (Snarey, 1985). Yet these are unique, or nearly so, in the history of humanity. In fact, the majority humans have claimed relational principles, such as those focusing on loyalty and obedience to authority (Henrich, 2020; Snarey, 1985), although such non-Western principles have varied greatly, from the limitless obligation to the shogun during the Tokugawa Shogunate in Japan (Kujala \& Danielsbacka, 2019) to the ancient Sanskrit ideal of selflessly embodying one's dharma, or socially constituted duty (Easwaran, 2007).

Principled behavior also varies within cultural communities, both in the particular principles people preach (Graham et al., 2009) and in the extent to which they abide by them (Herzog \& Golden, 2009). There is even intra-individual variation. People pick up new principles and can waver in their devotion, demonstrated in students' tendencies to adopt new values during college and then shift again once they enter an occupation (Crotty, 1967; Cullum \& Harton, 2007; Enoch, 1989; Newcomb, 1957; Pascarella \& Terenzini, 1991).

Why are humans principled? And why do they vary in the ways that they do? These questions have attracted scholarly attention since psychology's inception, with researchers focusing on such puzzles as our preference for consistency (Festinger, 1957; Lecky, 1945; Maslow, 1954) and the deontological nature of morality (James, 1891; Kohlberg, 1981; M. C. McGrath, 1922; Piaget, 1932). Yet, we argue, there is no overarching framework that explains the many constituent features of principled behavior or why it varies such that it does.

Here, we present a reputation-based theory of principled behavior. Building on the game theoretic literature on repeated games and reputations (Mailath \& Samuelson, 2006) and on research showing that features of human behavior function to influence others and court potential cooperation partners (e.g., Barclay, 2013; Baumard et al., 2013; McCullough et al., 2013; Mercier \& Sperber, 2011), we argue that much of principled behavior is a non-conscious impersonation of a "committed agent", or an individual with beliefs, incentives, or features of their psychology so extreme that they become exceptionally trustworthy. We use this hypothesis to explain the features comprising principled behavior and to make novel predictions otherwise unexplained by existing accounts.

In the next section, we show that existing accounts fail to explain principled behavior. We then present our theory, review its psychological foundations, and derive seven key predictions. We provide experimental, historical, and ethnographic evidence for those predictions and use our account to shed light on cognitive dissonance and moral licensing. We conclude by demonstrating how our theory helps explain puzzling social phenomena, including sacred values, universalist ethics, the expanding moral circle, and beliefs in supernatural punishment. Principled behavior is often a strategy for garnering trust, its particular form varying with the social ecology. 


\section{COMMITMENT AND IMPERSONATION}

\section{Existing accounts fail to explain principled behavior}

Principled behavior is composed of many behaviors, including consistently abiding by a principle, being unwilling to compromise or consider tradeoffs, and framing one's decision as reflecting a transcendental motive rather than an alternative, material incentive. Researchers have proposed a slew of explanations to account for these many behaviors, most of them disconnected.

Here, we review existing accounts and point out three major weaknesses. First, many, but not all, are proximate rather than ultimate. They explain principled behavior by pointing to primitive psychological processes (e.g., reducing aversiveness, increasing well-being) rather than explaining why it exists in the first place. Second, many accounts fail to consider the strategic dimension of principled behavior, treating it as a blind commitment rather than a flexibly deployed behavior. Finally, few, if any, accounts explain the constituent features of principled behavior within a single, overarching framework.

\section{Is principled behavior psychologically fulfilling?}

Many researchers have argued that people act principled to satisfy psychological ends. In explaining why people behave consistently, for instance, psychologists have argued that dissonance is aversive (Devine et al., 1999; Festinger, 1957; A. McGrath, 2017), that having a consistent identity is necessary for psychological well-being (Donahue et al., 1993; Lecky, 1945), and that people are motivated to act according to their perceptions of themselves (Bem, 1967; Swann \& Read, 1981). In considering why people treat values as non-negotiable, Tetlock et al. (2020, p. 96) observed that individuals "derive psychological benefits, such as self-esteem and mood enhancement, from reaffirming their solidarity with core societal values."

Intra-psychic explanations such as these confront two related limitations. First, they fail to parsimoniously predict variation. As we review later, the extent to which people act principled varies with whether they require others' trust, whether they proclaimed a value publicly, whether that value is acclaimed by others, and how informative current and previous actions have been, which hinges partly on others' incentives to perform those actions. It might be true that people derive well-being from acting consistently (Donahue et al., 1993; although see Cross et al., 2003; Suh, 2002) or that acting dissonantly in some contexts produces an aversive state (Cooper and Fazio, 1984; A. McGrath, 2017; Zanna \& Cooper, 1974; although see Priolo et al., 2019 for a recent, inconclusive meta-analysis). But intrapsychic explanations have difficulty predicting how the social environment moderates these internal states.

A second, related limitation is that intrapsychic accounts are proximate rather than ultimate (see Scott-Phillips et al., 2011). Proximate accounts identify the mechanics-the bowof a phenomenon. When applied to principledness, they gesture at presumably deeper psychological processes, such as that dissonance is aversive. In contrast, ultimate accounts identify the functional basis - the why - of the phenomenon. A functional account of principled behavior should explain why dissonance is aversive or why we derive self-esteem from embodying societal values. Functional hypotheses of psychological phenomena are especially useful, because they make testable predictions about how a behavior should vary with shifting circumstances (Muthukrishna \& Henrich, 2019). 


\section{COMMITMENT AND IMPERSONATION}

\section{Is principled behavior an adaptation for group-level success?}

An example of an ultimate-level explanation of principled behavior is that provided by Ginges and Atran (2011). They argue that principled behavior is an adaptation for group-beneficial collective action (see also Atran, 2016). Through a devotional blindness to achieving groupbeneficial values, low-power groups can "resist and often prevail against materially more powerful foes" (Atran, 2016, p. S193), selecting for a willingness to sacrifice oneself for ideals. Ginges and Atran acknowledge that genetic evolution is unlikely to produce such a tendency, given the freerider problem (in the absence of other benefits, defectors can outcompete altruists) and that genetic group selection was unlikely an important force in human evolution (Bell et al., 2009; Pinker, 2012). Thus, they point to cultural group selection as the primary evolutionary mechanism. As groups compete, beliefs and norms that inspire people to sacrifice themselves for group-beneficial ends spread, resulting in principled behavior.

It's true that martyrdom involves extraordinary self-sacrifice and likely leads to grouplevel benefits (Atran \& Henrich, 2010; see also Henrich, 2009). But examples of such selfsacrifice are rare (see, for example, the low frequency of suicide terrorists despite many people supporting the ideology: Lankford, 2014, p. 342), and principled behavior seems often to be rewarded with trust and other social rewards (e.g., Colquitt et al., 2007; Jordan et al., 2016; Simons et al., 2015). Moreover, people seem to use claims of principledness strategically. They deviate from their principles but then try to recast their decisions as conforming (Chanley et al., 1994). They describe friendships as incommensurable but drop them when the costs are too high (Posner, 1998). They demonstrate a commitment to the environment through recycling but buy large houses rather than small apartments. They make principled declarations, such as professing to "believe in free speech for all no matter what their views might be," and then permit exceptions when asked about them, like that the Klu Klux Klan should not be permitted on public television (McClosky \& Brill, 1983; see also Baron \& Leshner, 2000). The flexible, strategic nature of principledness suggests that it would be better understood as an individuallevel tactic than a group-level adaptation.

\section{Is principled behavior a decision-making heuristic?}

Another ultimate explanation posits that principled behavior is a decision-making heuristic. According to Bennis et al. (2010), people are unwilling to analyze costs and benefits when making moral decisions, because it is difficult to estimate the payoffs of different strategies. A cost-benefit analysis requires knowing (1) the outcomes of different decisions, (2) the likelihood of different outcomes, and (3) the payoffs of different outcomes-a feat that is near-impossible given informational and computational constraints. Thus, people might be better off abiding by rules, especially when cultural or genetic evolution can build adaptive decision-making heuristics that outcompete cost-benefit analyses (see also Gigerenzer, 2008; Sunstein, 2005). For instance, a person may always be loyal, because calculating the payoffs of being loyal in every circumstance is too unwieldy and it pays, on average, to be loyal (see also Atran, 2016, p. S194).

Evolution is certainly able to discover solutions better than individual cost-benefit analysis, and this has likely shaped human psychology dramatically (Barrett, 2015). Many behaviors are outputs not of explicit calculation, but of learned and evolved responses automatic responses to cues. But do humans refuse to deviate from principles because cost-benefit analyses 


\section{COMMITMENT AND IMPERSONATION}

are unreliable? Does someone always behave loyally because the payoffs of adjusting loyalty are too unpredictable? For much of principled behavior, the answer seems to be no ${ }^{1}$. People who claim to be principled about a given domain still consider trade-offs and deviate (Baron \& Leshner, 2000). When confronted about their inconsistency, they offer excuses and frame their behavior as conforming to a principle (K. M. McGraw, 1998; Scott \& Lyman, 1968). Parties conceal information about themselves to ward off perceptions of unprincipledness (Carlos \& Lewis, 2018) and adjust their behavior after others have pointed out their hypocrisy (Stone \& Fernandez, 2008b). These observations suggest that most principled behavior is not a blind heuristic but a strategically managed impression.

\section{Is principled behavior a strategy for garnering trust?}

Finally, principled behavior may be a strategy for attracting trust. Tedeschi and colleagues articulated an early version of this hypothesis (Tedeschi et al., 1971; Tedeschi and Rosenfeld, 1981; see also Baumeister, 1982). Responding to arguments that people behave consistently because dissonance is aversive (Festinger, 1957), they argued that cognitive dissonance findings can be explained by participants feeling compelled to maintain a positive, consistent impression with experimenters. Posner $(1998,2000)$ presented another version of this hypothesis to explain incommensurability in law and economics. People refrain from monetizing friendship, family, and the environment, he proposed, because doing so attracts cooperation partners.

Evolutionary and psychological researchers have recently used the logic of Tedesci's and Posner's theses to explain principled psychology more generally. Hoffman et al. $(2015,2018)$ developed game theoretic models showing that two components of principled behavior-refusing to consider tradeoffs and demonstrating that one is not pursuing an end for certain material gains - can evolve to attract trust. Experimentalists have tested predictions of these models, finding both that participants infer trustworthiness from intuitive and uncalculating decisionmaking (Capraro \& Kuilder, 2016; Everett et al., 2016) and that participants use uncalculating cooperation to signal trustworthiness (Jordan et al., 2016). Still, these trust-based accounts remain disconnected. They address isolated features of principled behavior but fail to link them in a coherent, unified explanation.

Frank (1988) offered a related explanation of emotions that is relevant for principled behavior. According to his account, emotions commit people to act in ways that would otherwise violate their self-interest. Experiencing anger commits people to retaliate no matter the costs. Sympathy commits them to selflessly help. As long as observers know that a person experiences those emotions, they will treat them in beneficial ways, such as ceding to an angry person or choosing a sympathetic one as a cooperative partner. Although Frank's account demonstrates how apparently non-strategic behavior can attract preferential treatment, some scholars criticize its assumptions about emotion and behavioral commitment as empirically and evolutionarily implausible (e.g., Dezecache et al., 2013; Mercier, 2020).

In the following sections, we develop the thesis that principled behavior is-with the exception of rare, extreme individuals - a strategy for attracting trust. Unlike existing theoretical work, our theory explains the many features of principled behavior, from never deviating to

\footnotetext{
${ }^{1}$ Trivially, we agree that principled behavior is not the result of conscious cost-benefit calculus but of decisionmaking algorithms built from adaptive processes such as natural selection or learning.
} 


\section{COMMITMENT AND IMPERSONATION}

transcendental justifications, within a single framework. Our account makes predictions about how principles and principled behavior should vary, and it explains one of the most puzzling features of principled behavior: that principled behavior should attract trust even when it appears strategic and, at times, hypocritical.

\section{Committed agents and impersonators: A reputation-based theory of principled behavior}

\section{The theory}

Drawing on game theoretic models developed to explain how firms and individuals develop desirable reputations (Mailath \& Samuelson, 2006), we explain principled behavior using a combination of rare, trustworthy "committed" agents and individuals trying to impersonate them to gain trust. Committed agents ${ }^{2}$ have beliefs, incentives, or other features of their psychology that lead them to never deviate from some maxim. They might, for example, sincerely believe in a moralistic supernatural punisher or feel eternally indebted to their leader. Given this extreme psychology, truly committed individuals exhibit a set of trustworthy behaviors:

1. They never deviate from the maxim, even at grave costs to themselves.

2. They never think about deviating from the maxim.

3. They pursue the maxim because of their extreme psychology rather than for other self-interested reasons.

Never deviating is crucial because it maximizes the gains from trust. If someone always abides by some maxim, you can always trust that they will act that way. Never deviating also invites trust in contexts where it would otherwise be hard to sustain, such as when circumstances are liable to change or impossible to predict.

Because people can trust that a truly committed person will never deviate, they interact with them differently than they would other individuals. If someone never deviates from being loyal, people will select that person as a cooperative partner over someone who considers costs and benefits. If someone never deviates from violently retaliating, even at a cost to themselves, people will avoid attacking them.

People who benefit from the treatment afforded particular committed agents should impersonate those agents. If people believe there are individuals who retaliate against aggression to the point of self-sacrifice, then other individuals will want to appear that way to deter violence (McCullough et al., 2013). If people believe that there are individuals who are invested, above all else, in remaining loyal, then individuals may benefit from masquerading as those individuals to attract cooperative partners (Baumard et al., 2013). If people believe that there are politicians who truly believe in their ideologies, or prophets who are invested in creating a wonderful utopia, or revolutionaries who care about liberation above all else, then politicians or prophets or revolutionaries benefit from appearing that way to gain followers. Game theorists have shown that committed agents can drastically affect aggregate, equilibrium behavior far beyond their numbers, because their mere existence induces imitators to behave in a more trustworthy fashion (Fudenberg \& Levine, 1989).

\footnotetext{
${ }^{2}$ Commonly referred to as "behavioral types", "commitment types", or "Stackelberg types" in the game theoretic literature on reputations and repeated games (Fudenberg \& Levine, 1989; Mailath \& Samuelson, 2006)
} 


\section{COMMITMENT AND IMPERSONATION}

In order to increase the odds of passing as trustworthy committed agents, impersonators should exhibit the three behaviors just listed. They should (appear to) never deviate from the maxim, never think about deviating, and pursue the maxim because of their extreme psychology rather than for alternative, self-interested reasons.

Observers update their beliefs about whether an actor is genuinely committed to a maxim on the basis of the actor's behavior. Impersonators should therefore strategically consider the signaling value of behavior, avoiding behaviors that would risk them being exposed as uncommitted. We expect that impersonators will build reputational capital as they act committed and other people become confident of their extreme psychology. If an impersonator unambiguously breaches the principle, however, they should discontinuously lose reputational capital, because observers gain strong countervailing evidence that the actor is not genuinely committed to the principle 3 (Figure 1). As a consequence, people should continue to behave principled once they build reputational capital. They should also try to convince observers that any ambiguous or compromising decisions are, in fact, consistent with their claimed, extreme, trustworthy psychology.

A

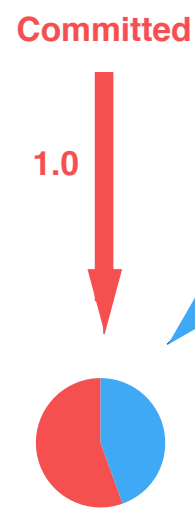

Follow the maxim
Uncommitted

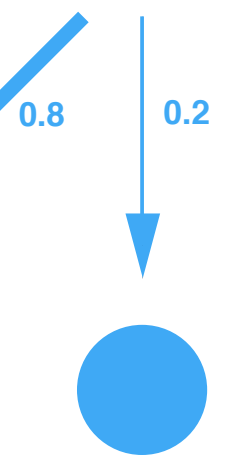

Don't follow the maxim
B

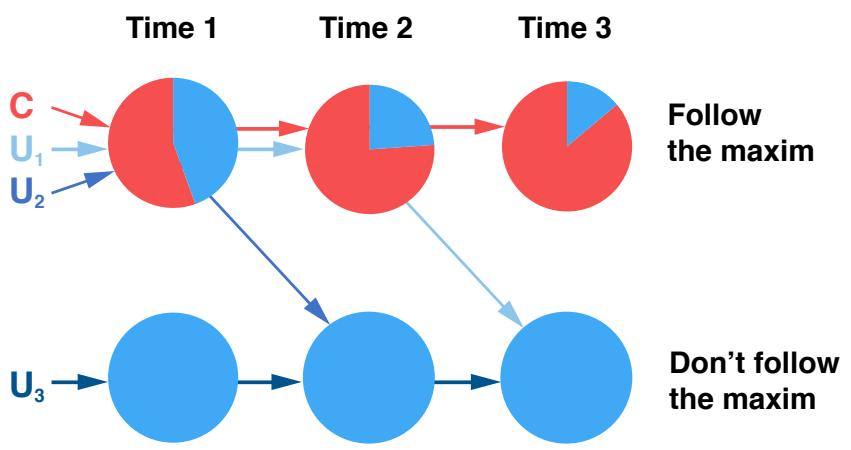

Figure 1. The logic of reputational capital. Circles denote posteriors of observers. In the circles, red is the probability an observed actor is genuinely committed to the principle; blue is the probability the actor is not. A: The hypothetical likelihoods with which committed and uncommitted agents either follow a maxim or do not. Because committed agents always follow the maxim, a person who does not follow the maxim unambiguously indicates they are not genuinely committed. B: How observers should update their beliefs as actors make decisions.

\footnotetext{
${ }^{3}$ The classic results in the literature on reputations and repeated games are that (1) observers continuously increase their posteriors that an actor is a Stackelberg type (corresponding with the committed agent in our account) the longer the actor behaves as a Stackelberg type would and (2) such posteriors decrease to 0 the first time an actor unambiguously deviates from Stackelberg behavior (Fudenberg \& Levine, 1989; D. M. Kreps \& Wilson, 1982). As a consequence, in equilibrium, (1) the likelihood that a strategic agent (corresponding with an imitator in our account) imitates a Stackelberg type increases continuously the longer they resemble a Stackelberg type and (2) once a strategic agent deviates, they are no longer motivated to imitate a Stackelberg type. These results hinge on two properties of Stackelberg types: They never deviate, and they induce preferential treatment.
} 


\section{COMMITMENT AND IMPERSONATION}

Red lines represent decisions made by a committed agent $(\mathrm{C})$; blue lines represent decisions made by three different uncommitted agents $\left(\mathrm{U}_{1}, \mathrm{U}_{2}, \mathrm{U}_{3}\right)$. The longer an uncommitted agent behaves as a committed agent would, the more reputational capital they accrue. Once an uncommitted agent unambiguously deviates, observers infer that they are not genuinely committed and the uncommitted agent loses their acquired reputational capital. For that reason, the cost of a breach increases the longer one appears committed to the principle.

Table 1 lists the key predictions of our theory. Heuristic accounts make none of these predictions. Neither do accounts in which principled behavior is an adaptation for intergroup conflict. We consider proximate accounts to be consistent with our theory, yet because they leave out the central role of trust, it's not always clear which predictions they make. Other trust-based accounts make predictions 1,2 , and 3, and, depending on the formulation, predictions 4 and 7 . With the exception of the game theoretic models that inspired our theory (Fudenberg \& Levine, 1989; D. M. Kreps \& Wilson, 1982), no account we know of, including existing reciprocity and norm enforcement theories (e.g., Boyd, 2017; Fudenberg \& Maskin, 1986; Nowak \& Sigmund, 2005; Trivers, 1971), makes predictions 5 and 6 . These are unique to an imitator model. This account is the only one to make all seven predictions.

Table 1. Predictions of our theory

Claim

Prediction

With the exception of rare committed agents, principled behavior is a strategy for garnering trust: Principled people are impersonating individuals with psychologies so extreme they would never deviate from a maxim.

1. People are trusted more when they act principled — that is, when they appear to never deviate from a maxim, never think about deviating, and pursue an action for the reason motivating committed agents rather than for alternative, self-interested reasons.

2. People who need trust are more likely to act principled.

3. People adopt the principles for which they need to be trusted.

Observers update their beliefs about whether an actor is genuinely committed to the principle on the basis of the actor's behavior.

4. Principled people will usually adjust their behavior contingent on its signaling value.

5. People are more likely to behave principled as they build up reputational capital for being principled.

6. An unambiguous breach will cause a dramatic and hard-to-restore loss in trust. 


\section{COMMITMENT AND IMPERSONATION}

\section{Principled people will usually recast ambiguous or compromising decisions as conforming to their principles.}

In the following subsections, we show that our theory is psychologically plausible. We show that (1) there are conditions under which a person might be compelled to never to deviate from some end, (2) people can evaluate the benefits from appearing some way and strategically but non-consciously act according to that appearance, and (3) people learn traits of other individuals through a process approximating Bayesian inference.

\section{Psychological foundations of the theory}

\section{Committed agents are psychologically plausible}

Our theory hinges on the existence, or believed existence, of rare individuals with psychologies so extreme that they would never deviate. There are many mechanisms that could compel such behavior. First, people might hold incorrect beliefs about the world. Manipulative leaders might exploit people's cognitive biases or informational asymmetries to induce self-serving behavior (Cronk, 1994; de Aguiar \& Cronk, 2011; Singh et al., 2017). As a result, or through other social and cultural evolutionary processes, people might be convinced to never deviate from a certain end. They might believe, for example, that bad deeds will be punished severely or that good deeds will be punished proportionately, motivating prosocial behavior regardless of the actual payoffs (Atran \& Henrich, 2010; Norenzayan et al., 2016; although see Mercier, 2020).

Second, an individual may never deviate because of reinforcement learning gone awry. Vallerand et al. (2003) document "obsessive passions", or activities people feel compelled to pursue, even to their own detriment (see also Curran et al., 2015; Vallerand, 2015). Obsessive passions can range from cycling to pathological gambling and, in surveys, are captured by items like "I have difficulty imagining my life without this activity" and "I am emotionally dependent on this activity". The reasons a person develops an obsessive passion include extreme external rewards, such as from coaches and parents, and extreme personality traits, like a strong tendency towards anxiety (Vallerand, 2015). Crucially, whenever rewards result in an obsessive passion, a person's cognitive mechanisms are erroneously responding to the activity's actual reward structure (e.g., Oberg et al., 2011).

Third, a person might qualify as a committed agent because of genuinely extreme incentives. They might be totally reliant on another person, as is the case with a kidnap victim or an isolated cult member. Or their livelihood might hinge completely on the success of some cause. In such cases, a person may benefit from pursuing the end at most or all costs. When a person's welfare is aligned with a cause to such an extent, it may be more efficient to use fast heuristics than to calculate costs and benefits (Gigerenzer, 2008). Although this resembles the heuristic theory presented earlier, we are only explaining why rare committed agents might engage in extreme behavior, not why people behave according to principles more generally.

There are other reasons a person might prioritize a goal above all others, such as social coercion or mental health problems (see, for example, the pressures influencing some suicide terrorists: Lankford, 2014). Our account neither requires that such extreme behavior is common 


\section{COMMITMENT AND IMPERSONATION}

nor makes a strong claim about which process generates the behavior. Rather, we only claim that processes exist that can plausibly produce extreme, truly committed people.

People learn self-serving impressions and act according to them

Our account next assumes that people learn the social benefits from appearing a certain a way and then strategically act according to that image. This is a safe assumption, supported by research on topics as diverse as self-presentation on social media (Chua \& Chang, 2016; Lyu, 2016), signaling among hunter-gatherers and horticulturalists (Bliege Bird \& Smith, 2005; Gurven et al., 2000; Hawkes \& Bird, 2002), and children managing reputations for fairness (Shaw, 2016; Shaw et al., 2014). People constantly tailor their behavior to garner reputational benefits (Engelmann et al., 2012; Goffman, 1959; Griskevicius et al., 2010; Milinski, 2016).

Importantly, strategic impression management is not necessarily conscious. Our hypothesis is that people have cognitive mechanisms designed to act strategically, not that they deliberately and reflectively plan how to impersonate committed agents. In fact, given that people benefit from appearing blindly devoted to their principles, principled behavior may be instantiated so that its strategic deployment is outside of reflective awareness (see von Hippel \& Trivers, 2011).

\section{People update their impressions of others through a process approximating Bayesian inference}

Finally, we assume that people update their impressions in a way that shares two key features with Bayesian inference. First, people entertain different hypotheses about what drives others' behavior. For example, a person might consider whether another individual believes in a punitive god (hypothesis 1) or doesn't (hypothesis 2). Second, people update the probability of these hypothesized drivers as they observe others' behavior. As someone acts in a way consistent with a Believes-in-God model, for instance, that hypothesis should be updated with a higher likelihood.

Psychological evidence is consistent with these assumptions. Not only do people update their beliefs about others on the basis of behavior, but this is one of the most enduring and wellstudied topics in psychology (Asch, 1946; Gilbert, 1998; Malle, 2011; Pettigrew, 1979).

Granted, cultural communities vary in the extent to which people seem to make these inferences (Henrich, Heine, et al., 2010), and our beliefs about others can sometimes to be resistant to contradicting evidence, especially when strong priors and ambiguous evidence lead us to consider ad hoc hypotheses (Gershman, 2019; Kim et al., 2020). Nevertheless, the propensity to use other people's behavior to update inferences about their traits seems to be a human universal (Choi et al., 1999).

\section{Addressing predictions about principled behavior}

In outlining our theory, we derived key predictions that our account makes about principled behavior (Table 1). Here, we address them. The historical, ethnographic, and experimental evidence we review spans temporal and geographic diversity, suggesting that our explanation of principledness applies not only to contemporary Westerners but to humanity more broadly. 


\section{COMMITMENT AND IMPERSONATION}

As we acknowledged, predictions 1 through 3-and, depending on the formulation, 4 and 7-are shared by other accounts. Nevertheless, we review all 7 both to comprehensively address the predictions generated by this account and because, as far as we know, the empirical evidence for these predictions has not been reviewed elsewhere.

\section{Prediction 1: Principled people are trusted more}

Many lines of evidence show that people are trusted more when they are thought to abide by a principle. Colquitt et al. (2007) conducted a meta-analysis of the antecedents of trust. Analyzing 35 samples ( $N=7,284$ subjects), they found a strong relationship between trust and integrity, where integrity was "the extent to which a trustee is believed to adhere to sound moral and ethical principles" (Colquitt et al., 2007, p. 910). More recently, Simons et al. (2015) analyzed 22 distinct datasets and reported a similarly strong relationship between followers' trust and leaders' behavioral integrity, the latter defined as "the perceived pattern of alignment between an actor's words and deeds or the extent to which actors are seen to keep promises, 'walk the talk' and 'practice what they preach"' (Simons et al., 2015, p. 832).

Experimental work shows that people who exhibit the characteristics of principled behavior also attract greater trust. People are trusted more when they consistently do not deviate (Aaker et al., 2004; Allgeier et al., 1979), they don't apparently consider the payoffs of acting (Cabrales et al., 2017; Capraro \& Kuilder, 2016; Critcher et al., 2012; Jordan et al., 2016; Sacco et al., 2017), and they strongly believe or care about their position (Zlatev, 2019).

Similar findings have been found in management and organizations (Effron, O'Connor, et al., 2018; Palanski \& Yammarino, 2007). In a survey of 228 MBA students across 46 nations, the more students remembered a manager's words and deeds as chronically misaligned, they less they trusted the manager (Effron, Markus, et al., 2018). When employees see managers acting in ways inconsistent with their values, employees perform poorly, are absent more often, turn over at higher rates, and express weaker commitment (A. L. Davis \& Rothstein, 2006; Dineen et al., 2006; Greenbaum et al., 2015; Kannan-Narasimhan \& Lawrence, 2012; Prottas, 2008; Vogelgesang et al., 2013).

These findings are also echoed by research on politicians (Andreottola, 2018; Bhatti et al., 2013; Doherty et al., 2016; Enli, 2015; H. S. Hoffman \& Carver, 1984; Hummel, 2010; Kartik \& McAfee, 2007; T. A. Kreps et al., 2017; Tomz \& Van Houweling, 2010, 2016). US undergraduates express more favorable opinions of politicians who refuse to consider trade-offs (Ryan, 2017; Tetlock, 2000) and are consistent (Carlson \& Dolan, 1985), and they expect voters to do the same (McCaul et al., 1995). Compared to consistent politicians, ones who act "out-ofcharacter" are seen as more changeable and relatively uninfluenced by internal causes (Sigelman \& Sigelman, 1986). Tavits (2007) analyzed how voters responded to policy shifts in Australia, Canada, Japan, New Zealand, the United States, and Western Europe from 1960 to 1980. She found that voters rewarded shifts on pragmatic issues unrelated to principles, while they penalized politicians who departed on principled issues. Politicians seem aware of their constituents' preference for principledness, revealed both in a survey of a North Dakota state representatives (McCaul et al., 1995) and in ad campaigns that paint political competitors as flip-floppers (“John Kerry, Flip-Flopper?,” 2004; Naughton, 1976).

Trusting people who appear principled is not restricted to the contemporary, industrialized West. The ancient Chinese philosopher Mozi (c. 470 - c. 391 BC) believed that 


\section{COMMITMENT AND IMPERSONATION}

suffering and warfare would be reduced if people were universally compassionate towards each other. In urging people to adopt the principle, he pointed out how sincerely abiding by impartial compassion would attract others' trust, especially compared to being partial towards one's family (Mei, 1973, p. 90):

Suppose [an impartial person is] sincere in word and decisive in deed so that their word and deed are made to agree like the two parts of a tally, and that there is no word but what is realized in deed, then let us consider further: Suppose a war is on, and one is in armour and helmet ready to join the force, life and death are not predictable... Now (under such circumstances) let us inquire upon whom would one lay the trust of one's family and parents. Would it be upon the universal friend or upon the partial friend? It seems to me, on occasions like these, there are no fools in the world. Even if he is a person who objects to universal love, he will lay the trust upon the universal friend all the same.

People everywhere resent individuals who are inconsistent, insincere, or who do not practice what they preach. The Songhai of West Africa said that hypocrites felt with two hearts (compare with the English phrase "two-faced") and were a reason for droughts, epidemics, and catastrophes (Stoller, 1989, p. 181). Tongans compared people who only act honestly when being observed to cats who eat chicken flesh as soon as people leave (Collocott, 1922, p. 71). The Maori value what they call pono, meaning "true, that is, genuine (not hypocritical) and loyal in relations with others... Pono is a quality especially required of those who occupy positions of leadership in the whānau [extended family]" (Metge, 1995, p. 87). In their folktales, the Kogi of Colombia contrasted saintly images of teachers with more sinful ones. The saintly figure "never demands from his pupils more than he himself is willing to give; he suffers patiently with them and is a model of self-control and wisdom" (Reichel-Dolmatoff, 1976, p. 274). His foil, in contrast, is "a vicious hypocrite who stuffs himself with food while his disciples are fasting", a "lecherous old man who seduces nubile girls while publicly preaching chastity."

\section{Prediction 2: People who require trust act more principled}

Experimental work shows that people are more likely to act principled when they require trust. They don't apparently consider the costs and benefits of acting (Jordan et al., 2016) and act in ways that don't apparently further their self-interest (Fehrler \& Przepiorka, 2013). On the flip side, as people become less beholden to others, they seem to more easily violate principles. Powerful people are disinhibited from normal moral constraints and act in ways that are more self-serving (Lammers et al., 2015; Piff et al., 2012). Across five experiments, Dutch students made to felt more powerful were more likely to depart from their expressed moral rules (Lammers et al., 2010). And professionals who consider themselves more powerful are more likely to entertain infidelity and, according to self-reports, commit adultery at a higher rate (Lammers et al., 2011).

The tendency for people who rely less on trust to diverge from their principles is not restricted to contemporary Westerners. Alexander the Great was committed to the Greek and Macedonian ideal of a king who was first among equals. But after he conquered Persia and Central Asia, he began to demand that people prostrate themselves before him in "the posture of 


\section{COMMITMENT AND IMPERSONATION}

a slave before his master or a worshiper before a divinity" (Freeman, 2011, p. 262). In his study of political support in a Hausa village in Niger, Faulkingham (1971) described how chiefs gained legitimacy by acting in accordance with shared values, such as conservatism and a localized solidarity. But he also noted that power corrupted chiefs, leading them to diverge from their values and sometimes jeopardize their position. Ibhawoh (2017) listed examples throughout post-colonial Africa of ideological revolutionaries who became dictators and, once powerful, veered from their original principles. Kwame Nkrumah, for instance, was a Ghanaian revolutionary who campaigned for democracy, human rights, and independence during the British colonial era. He was arrested twice, demonstrating his commitment to his ideals. As Ghana's first prime minister, he began by affirming a commitment to civil liberties, including freedom from arbitrary arrest. Once in power, however, he abolished regional assemblies, consolidated political power, repealed human rights protections, and instituted acts allowing arbitrary arrest.

\section{Prediction 3: People adopt the principles for which they need to be trusted}

People should be principled about those behaviors that are most important for attracting trust. This means, for instance, adopting the principles that followers look for in leaders, that people look for in cooperative partners, or that discourage people from attacking. Lawyers, for instance, should be principled about assisting their clients, doctors about the health of their patient, and scientists about producing good knowledge, but none of them necessarily should care about advancing the state. Merchants should be principled about pleasing the customer above all else, a position clearly demonstrated in mantras like "The customer is always right" and "Customer satisfaction is our number one priority". A party's principles should vary according to who their audience is and how they want that audience to interact with them.

To our knowledge, there has been little experimental work directly testing whether people adopt the principles that ensure trust. Still, current findings are consistent with our prediction. In studies with Western participants, researchers found that individuals in close relationships shift their values towards principles their partners see as important (J. L. Davis \& Rusbult, 2001; Kalmijn, 2005) and that such shifts result in greater trust and attraction (Reid et al., 2018). We expect that much of the variation in principles reflects the behaviors for which people want to be trusted, a point which we return to at the end of this article.

\section{Prediction 4: Principled people usually adjust their behavior contingent on its signaling value}

Our account predicts that impersonators should be responsive to the signal value of their behavior. As individuals swayed by costs and benefits ("greedy" individuals) are incentivized to make particular decisions, people impersonating as committed types should avoid making those decisions so as not to expose themselves (Figure 2). 


\section{A}

WITHOUT MATERIAL INCENTIVES

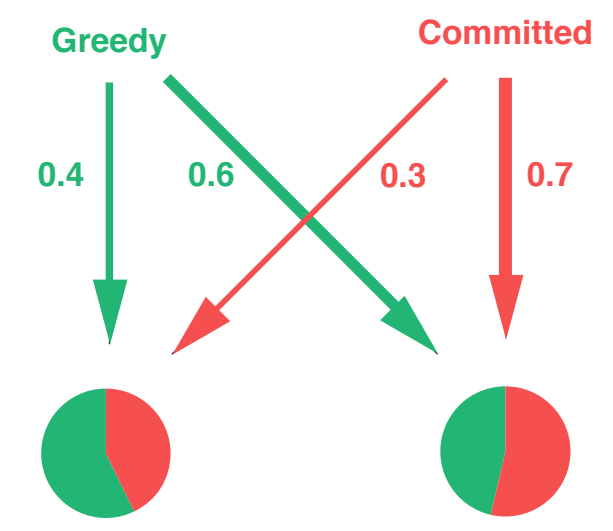

Take the deal

Reject the deal

\section{B}

WITH MATERIAL INCENTIVES

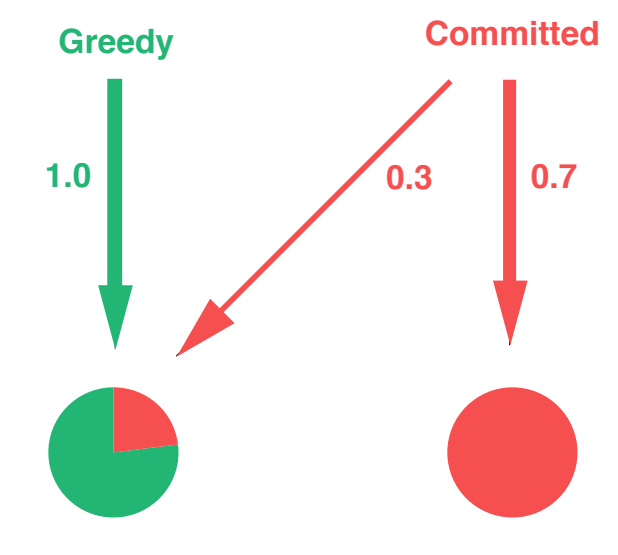

Take the deal

Reject the deal

Figure 2. As "greedy" individuals (those purely swayed by immediate costs and benefits) are incentivized to make particular decisions, people impersonating committed agents should make the opposite choice to avoid pooling with them. The panels show the likelihoods with which greedy people and committed agents choose whether to take a hypothetical deal. Circles denote posteriors of observers. In the circles, green is the probability an observed actor is greedy; red is the probability they are a trustworthy committed agent. A: Roughly similarly proportions of greedy people and committed agents take and reject the deal, so the decision is minimally informative. B: Added material incentives push greedy people to take the deal. As a result, impersonators (not shown) should make the opposite decision, even though the likelihood that a committed agent makes each decision remains unchanged.

Atran, Ginges, Medin, and colleagues documented evidence consistent with this prediction in a series of experiments with Indians, Indonesians, Iranians, Israelis, and Palestinians (Dehghani et al., 2009, 2010; Ginges et al., 2007; Ginges \& Atran, 2009; Sachdeva \& Medin, 2009). The researchers found that participants who treated certain values as inviolable responded with greater outrage and less approval to negotiations over those values when additional incentives were included. In one experiment, they identified Iranians who regarded the Iranian nuclear energy program as something to be maintained no matter the costs (Dehghani et al., 2010). They presented these participants with hypothetical negotiations in which Iran and Israel both surrendered their nuclear facilities, although for some of the participants, they added material incentives to the negotiations, such as that Iran receives $\$ 40$ billion or is sanctioned if it doesn't capitulate. As predicted, participants presented with these additional material incentives expressed more anger and less approval for the negotiations. People uncommitted to Iranian sovereignty are more likely to be swayed by these incentives, giving principled people more reason to distinguish themselves.

Researchers have shown other instances in which principled people avoid behaviors that unprincipled people are likely to perform, even when truly committed agents' behavior would remain unchanged. Bénabou and Tirole (2006) reviewed evidence that people are less likely to engage in moral behavior when it is incentivized. Because monetary incentives attract greedy 


\section{COMMITMENT AND IMPERSONATION}

individuals, a principled person should avoid performing that behavior so as not to be seen as unprincipled. Relatedly, Hoffman et al. (2018) modeled how, in some circumstances, principled people should behave modestly so as avoid creating an impression of being reputation-minded. Insofar as talking about one's successes indicates that one is pursuing reputational gains, principled people should refrain from doing so. A successful artist or academic might be invested in maintaining an image that they are committed to "doing good work", and, for that reason, hesitate before mentioning their successes in casual conversation.

\section{Prediction 5: People are more likely to behave principled as they build up reputational capital for being principled}

Our account predicts that people will be more likely to act according to a principle as they build up reputational capital for abiding by that principle. This means that acting according to a principle even once should increase the likelihood that a person will act according to it in the future. We discuss this prediction in detail, and connect it prominent social psychological phenomena, in the section below entitled "Explaining cognitive dissonance and foot-in-the-door effects".

\section{Prediction 6: Breaches cause a discontinuous loss in trust}

According to our account, trust should accumulate continuously as people become confident that a person is committed to a principle. However, whenever a person's actions reveal that they are not committed (such as if they choose not to follow the maxim in Figure 1), trust should drop dramatically, because the action provides strong, countervailing evidence. Trust should also be harder to regain after these breaches, because others have diagnostic evidence that a person is not truly committed.

Several lines of evidence show that unambiguous violations cause a dramatic and hard-torestore loss in trust. The likelihood that a politician recovers from a sex scandal hinges largely on how much the behavior departs from the politician's expressed values (Grover \& Hasel, 2015). And researchers note that, in marriages in which both spouses commit to sexual monogamy, "once an affair is disclosed it becomes impossible to completely repair the degree of trust that was initially established. Even couples that wish and work very hard to rebuild their marriage go through long periods of struggle and distrust" (Winek \& Craven, 2003, p. 263).

The discontinuous loss of trust appears in relationships with brands, too. Aaker et al. (2004) conducted a longitudinal study in which they invited community members to participate in a beta test for one of two photo websites: a "sincere" brand, which appeared devoted to professionalism and the customer experience, and an "exciting" one, which was built around energy and fun. They found that, over time, customers became more loyal to the sincere website than the exciting one, and, as expected, following a transgression, customers' loyalty dropped more towards sincere brands. Notably, that loss of trust rebounded less for sincere brands than exciting ones. People who claim to be principled and then fail to embody that value have a harder time rebuilding trust than people who don't make those claims (Jordan et al., 2017).

The intuition that someone who deviates should not be easily trusted often appears in language. We searched phrases using the structure "once a(n) X, always a(n) X" in English books published between 1800 and 2008. Of the 16 most common phrases that included words about 


\section{COMMITMENT AND IMPERSONATION}

people, 5 were about antisocial behavior (alcoholic, addict, bitch, criminal, thief), while only 1 was prosocial (friend). ${ }^{4}$ Ethnographers have recorded similar sentiments around the world, including among the Santal of South Asia (on witches: Mukherjea, 1962, p. 342), the Shona of southern Africa (on witches: Gelfand, 1967, p. 27), the Tiv of West Africa (on thieves: Bohannan, 1968, p. 164), and the Xokleng of Brazil (on murderers: Henry, 1941, p. 108). The same intuition even appears in proverbs. The Somali said, "The leopard's cubs are not held on the lap" (Cerulli, 1959, p. 187), meaning that a precedent of transgression makes a person untrustworthy.

Given that trust is harder to recover after a breach, we also predict that, once the breach occurs, a person will be less motivated to act principled ${ }^{5}$. For instance, we expect that judges with a political incentive to vote against their judicial philosophy will override their philosophy not only in that case but in subsequent ones as well. Future research should test this prediction.

\section{Prediction 7: Justifications retain trust when actions are ambiguous or apparent transgressions}

Figure $2 \mathrm{~B}$ shows a scenario in which both committed types and greedy individuals would take a hypothetical deal, although the action is much more likely to be performed by a greedy person. We expect that, in situations such as this, people passing as committed who make compromising decisions will recast those decisions as conforming to principles. Moreover, principled people should be trusted more when they justify compromising decisions compared to when they do not.

A large body of experimental research shows that justifications retain trust when an action is ambiguous. American undergraduates evaluate politicians more positively when they justify breaches in moral principles than when they shift blame or deny the transgression (Chanley et al., 1994; K. M. McGraw, 1998; K. M. McGraw et al., 1995). Participants on Amazon Mechanical Turk supported policies more when hypothetical leaders justified them as satisfying moral principles than when they used pragmatic arguments based in costs and benefits (Van Zant \& Moore, 2015). And after Bill Clinton allowed campaign contributors to stay in the Lincoln bedroom of the White House, students who supported Clinton were less outraged when the scenario was cast as pursuing a separate principle (loyalty to friends) than when it was cast in economic terms (selling the bedroom for campaign donations) (A. P. McGraw \& Tetlock, 2005).

Recasting an action as conforming to a principle is more important when the actor was seen as principled in the first place. In one study, undergraduates rated pharmaceutical companies and religious organizations as more committed to communal aims than credit unions and software companies (A. P. McGraw et al., 2012). As predicted, those undergraduates felt more favorably towards pharmaceutical and religious organizations when they justified seeking money in communal aims, like workshops or forums for members, compared to getting money for economic ends, like rebranding or hiring a celebrity endorser. Students' perceptions of

\footnotetext{
${ }^{4}$ We searched the following phrases in the Google Ngram Viewer using the default settings (between "1800" and "2008" from the corpus "English (2012)" with a smoothing of " 3 "): once a * always a; once an * always an; Once a * always a; Once an * always an [semicolons separate distinct searches]. The most common words were addict, alcoholic, artist, bitch, captain, citizen, criminal, Englishman, friend, German, highway, Jacobin, Jerw, mortgage, priest, sailor, subject, and thief.

${ }^{5}$ In fact, because of this anticipated effect, people may even look the other way when a principled person transgresses, allowing the impersonator to save face and continue to pass as a committed agent.
} 


\section{COMMITMENT AND IMPERSONATION}

unprincipled credit unions and software companies, meanwhile, were minimally affected by the justifications they used.

\section{Explaining social psychological phenomena}

In this section, we apply the logic of committed agents and impersonators to explain prominent social psychological phenomena-specifically, cognitive dissonance, foot-in-the-door effects, and moral licensing. We argue that these diverse behaviors result from cognitive mechanisms designed to manage a trustworthy reputation ${ }^{6}$. People exhibit cognitive dissonance because they are motivated to salvage their reputation after apparently unprincipled behavior. They exhibit foot-in-the-door effects because of a psychology serving to reap the benefits of accrued reputational capital. And they are subject to moral licensing because they can risk otherwise compromising actions after conclusively protecting themselves against damaging accusations.

As with the predictions just reviewed, the evidence we present is difficult to reconcile with alternative accounts for principled behavior, such as the heuristic and group-level adaptation accounts. And although these predictions are consistent with proximate accounts, they are difficult to explain without considering the essential role of trust.

\section{Explaining cognitive dissonance and foot-in-the-door effects}

Cognitive dissonance is among the most well-documented and widely studied phenomena in psychology (Cooper, 2007; Festinger, 1957; Harmon-Jones \& Mills, 2019). People are driven to act consistently, so much so that this tendency can be exploited for persuasion and behavioral change (Dickerson et al., 1992; Osbaldiston \& Schott, 2012). If they advocate a value, either spontaneously or because they're asked to, and are then reminded of how their behavior diverges from that value, they adjust their behavior to conform (Priolo et al., 2019; Stone \& Fernandez, 2008 b 2008a). If they are asked to speak highly of an activity, they are more likely to report liking it later, even if it's boring and monotonous (Festinger \& Carlsmith, 1959). The tendency to behave consistently also manifests in the foot-in-the-door effect. Once a person complies with a small request (like putting a sticker in their window), they are more likely to comply with a related, larger one (like putting a sign in their yard) (Beaman et al., 1983; Burger, 1999).

According to our account, cognitive dissonance and foot-in-the-door effects emerge from cognitive mechanisms serving to manage a trustworthy reputation (see also Tedeschi et al. 1971). ${ }^{7}$ Adjusting one's beliefs to match one's behavior, or adjusting one's behavior to match professed beliefs, or adjusting one's behavior after one has been exposed as hypocritical—all are strategies for rescue one's reputation from appearing unprincipled about a given maxim.

Our ultimate-level account is potentially compatible with proximate explanations by Festinger and others. Festinger (1957) argued that dissonance is arousing and aversive and that it

\footnotetext{
${ }^{6}$ Our argument is that the underlying cognition functions to manage a trustworthy reputation, not that it does so optimally in all settings. Given that those cognitive mechanisms can be evoked by reliably occurring social stimuli, socially strategic behaviors can be triggered even in anonymous laboratory settings.

${ }^{7}$ Researchers sometimes use "cognitive dissonance" to refer to a wider set of behaviors than those discussed here, such as the free choice paradigm, in which a person's valuation of an item increases (or their valuation of an alternative decreases) after they choose that item (Shultz et al., 2011). Our account does not apply to behaviors included under this broader usage.
} 


\section{COMMITMENT AND IMPERSONATION}

thus compels change (Harmon-Jones \& Mills, 2019; A. McGrath, 2017). Others have since recast his explanation, arguing out that dissonance occurs when one's self-concept is threatened (Aronson, 1969, 1992) or that people are acting according to their perceptions of themselves (Bem, 1967). But these explanations all beg the question. Why should a person try to maintain a coherent self-concept? Which behaviors are regarded as threats to the self-concept? Which selfconcepts will people try to build? In short, these explanations fail to address the functional basis of our consistency motivation.

Our explanation, building on earlier specifications by Tedeschi and colleagues (Tedeschi et al., 1971; Tedeschi \& Rosenfeld, 1981), overcomes this problem. Humans are endowed with cognitive mechanisms designed to manage their reputations. People change their beliefs after acting dissonantly not because that behavior is inconsistent, but because it precludes them from passing as principled. For example, a subject who tells another person that a boring activity is enjoyable risks apparently violating a desirable principle - in this case, honesty. Their subsequent belief change allows them to maintain a trustworthy impression. Meanwhile, people exhibit footin-the-door effects because of a psychology designed to reap the benefits of accrued reputational capital. Once a person acts according to a principle, they benefit from continuing to do so, given both the benefits of building a reputation for being principled and the loss of trust accompanying a violation (Figure 1).

Because this account centers on the reputational consequences of dissonance and inconsistency, it makes predictions about how the social environment should moderate people's impulses to remedy inconsistency. Specifically, we predict that the effects of dissonance should be affected by (1) whether an act of dissonance is public or private, (2) whether people can plausibly deny being unprincipled, and (3) whether people proclaim attitudes that are socially valued.

\section{People adjust their behaviors and beliefs more when proclamations are public}

If people respond to dissonance to protect themselves from appearing unprincipled, public proclamations should induce more change than private ones. Experimental research supports this prediction (Ashmore and Collins 1968; Stone and Fernandez 2008a; Tedeschi et al. 1971; although see Fried 1998). For example, French students who publicly argued the advantages of following driving rules were more likely to distribute flyers than those who privately wrote an essay (Collani, 2003). American undergraduates who delivered a statement to an audience were more affected by dissonance than those who only prepared the speech or read about the importance of performing a behavior (Aronson et al., 1991; Stone et al., 1994, 1997). And when Japanese high schoolers made public audio tapes recording their opposition to coeducation, those who also recorded their name and grade later reported greater support for abolishing coeducation than those who did not include their personal information (Sakai, 1981). Finally, American undergraduates shifted their beliefs to match their proclamations more when interacting with ingroup members than when interacting with out-group members (Malkis et al. 1982), presumably because in-group members' opinions have greater bearing on one's reputation.

People adjust their attitudes more when dissonant behaviors appear conclusively unprincipled 


\section{COMMITMENT AND IMPERSONATION}

If dissonance compels change because it threatens a reputation for being principled, then the effects of dissonance should decrease as people can provide alternate justifications for their behavior. The more one can justify a compromising action, the less their reputation is threatened and thus the less need there is for an attitudinal change. This prediction is well-supported. Participants provided with justifications for acting dissonantly-including those who have little choice, who have the opportunity to explain themselves, who are paid a substantial amount, and who share responsibility with other people-feel less compelled to adjust their beliefs than individuals lacking those justifications (Ashmore \& Collins, 1968; Festinger \& Carlsmith, 1959; Helmreich \& Collins, 1968; Linder et al., 1967; Zanna \& Cooper, 1974; Zanna \& Sande, 1987).

\section{People adjust their attitudes more when the new attitudes are more socially acclaimed}

Finally, we expect that people who dissonantly proclaim a new attitude will more likely to maintain it when it is socially valued. This seems to be the case. In a study with students at University Bordeaux 2, Voisin et al. (2013) first conducted a survey and found general support for a ban on smoking in public places. They then had a separate group of students write arguments either in support of or against the ban. They found that students who privately started out against the ban and then were asked to write arguments in support of it shifted towards supporting the ban. Meanwhile, students who started out in support of the ban and then wrote arguments against it were much less likely to shift their opinions. Both sets of students would be hypocrites if they did not adjust their beliefs. But students who went from an unpopular to a popular attitude likely gained more reputational benefits than those who went from a popular one to an unpopular one. Whether dissonance compels change hinges on the reputational consequences of adopting a new position.

\section{Explaining moral licensing}

Despite our apparent impulse for consistency, researchers also observe what they call "moral licensing": Acting one way often licenses someone to do just the opposite (Blanken et al., 2015; Mullen \& Monin, 2016). Participants given the opportunity to disagree with blatantly sexist statements were more likely to choose a male candidate for a stereotypically male position (Monin \& Miller, 2001). Participants who endorsed Barack Obama were more likely to say that a job is more appropriate for a white person than a black person (Effron et al., 2009). And participants who engaged in environmentally friendly behavior were less likely to report environmental concerns afterwards (Meijers, 2014).

According to our account, moral licensing behaviors occur because individuals want to demonstrate that they are not committed to unappealing, negative ends. To this point, we have discussed committed agents who are socially acclaimed. But our account makes similar predictions for the inverse situation: when committed agents are socially derided. Just as people should manage their behavior to maintain impressions that they are committed to socially valued principles, they should also act in ways that demonstrate they are not the worst types of individuals, such as extremely racist, sexist, or antisocial individuals. Moreover, in the same way that an unambiguous breach can demonstrate that a person is not committed to a positive maxim (Figure 1), it can also demonstrate that a person is not a committed to a negative one. 


\section{COMMITMENT AND IMPERSONATION}

By this logic, we expect moral licensing when (a) an individual simply wants to show that they are not a negative committed agent, (b) a first act provides strong evidence that that's the case, and (c) the second act, regardless of how one behaves, is not sufficiently informative to override the evidence from the first act. This logic predicts that whether licensing occurs depends on (1) what a person wants to indicate about themselves and (2) the amount of information conveyed by the two actions.

\section{Whether licensing occurs depends on what a person wants to indicate about themselves}

According to our account, whether licensing occurs depends on what people want to indicate about themselves. If a person benefits from being seen as a trustworthy, committed person (e.g., principled about fighting sexism), we expect them not to exhibit licensing. A principled antisexist, for instance, will never be prejudiced towards women and should therefore be less subject to moral licensing. In contrast, if a person simply means to establish that they are not the worst type (e.g., not an extreme sexist), then we expect licensing.

Experiments on moral licensing show that people who are more invested in being principled about an issue are less susceptible to moral licensing. Effron et al. (2009, Study 3) found that subjects who endorsed Obama were more likely to afterwards allocate hypothetical money to a white organization over a black one-but only if they scored high on the Modern Racism Scale. People who reported strong, anti-racist attitudes failed to exhibit moral licensing, presumably because they are committed to maintaining a principled reputation. Meijers (2014, Study 3 ) found that subjects who made environmentally friendly decisions subsequently expressed lower environmental concerns-but again, only if they held a weak environmental identity. People who answered affirmatively to statements like "I value being an environmentally friendly person" (Study 3.1) and "I am willing to make personal sacrifices for the sake of slowing down pollution even though the immediate results may not seem significant" (Study 3.2) reported high pro-environmental concerns, regardless of whether they made an environmentally friendly decision first. Finally, in Study 1 of Monin and Miller's (2001) original experiment, only male participants exhibited sexist moral licensing. Men who had the opportunity to disavow sexist statements were more likely to favor male candidates, whereas women who disavowed sexist statements favored women candidates just as frequently as women who did not have the opportunity to disavow sexism. Although the researchers did not measure male and female participants' opinions about sexism, it seems likely that female participants are more often principled about fighting it. People who are principled about positions are much less subject to moral licensing, likely because they are invested to maintaining a positive principled reputation rather than disavowing a negative one.

\section{Whether licensing occurs depends on how ambiguous or diagnostic actions are}

Our argument predicts that people should exhibit moral licensing more when the first action conclusively establishes that they are not the negative committed type (e.g., an extreme sexist) and the second action is sufficiently ambiguous that it doesn't override the first. These predictions are supported by experimental work (Mullen \& Monin, 2016). Participants in the United States and France who imagined doing environmentally friendly behaviors voluntarily rather than because of external incentives were more likely to engage in self-interested behavior 


\section{COMMITMENT AND IMPERSONATION}

(Clot et al., 2013; Khan \& Dhar, 2006). Voluntary work is a better indication that an individual will behave prosocially without monetary incentives (i.e., they are not totally greedy), freeing them to engage in selfish behavior afterwards. Similarly, Brown et al. (2011) gave participants the opportunity to indicate their prosocial intent and then cheat, varying how ambiguous each decision was. Participants who could clearly indicate their prosocial intent and then plausibly deny cheating were much more likely to cheat than those who didn't get a chance to indicate their intent or those who couldn't plausibly deny cheating. Licensing is more likely when a person first establishes that they are not an untrustworthy committed agent and then can easily justify apparent transgressions (see also Effron \& Monin, 2010; Rotella et al., in preparation).

\section{Explaining sociological puzzles}

Many of our most puzzling social behaviors can be explained within the proposed framework. Here, we show how sacred values, universal moral ethics, and beliefs in moralistic deities can all be explained, at least partly, as principled behaviors deployed for their relevant ecologies.

\section{Explaining sacred values and taboos}

Psychologists use the word "sacredness" to refer to "the human tendency to invest people, places, times, and ideas with an importance far beyond the utility they possess. Tradeoffs or compromises involving what is sacralized are resisted or refused" (Graham \& Haidt, 2011). Sacred entities include human life (Tetlock et al., 2000), Kurdistan (Atran, 2016), the American flag (Nahmod, 1991), and voting (Banerjee, 2007).

By our account, treating some entity as sacred is an exemplar of principled behavior: People consistently value some entity far beyond its utilitarian value to attract social trust (or, more specifically, because of cognitive mechanisms functioning to garner trust). Several lines of evidence support this interpretation. First, sacredness exhibits those features characteristic of principled behavior. People should never deviate from prioritizing a sacred entity (except for other ends that are sacred); they should never think of deviating, including never considering a sacred value in cost-benefit terms; and they should justify any apparent deviations (Atran \& Axelrod, 2008; Baron \& Spranca, 1997; Ginges \& Atran, 2015; A. P. McGraw et al., 2012; A. P. McGraw \& Tetlock, 2005; Roth, 2007; Tetlock et al., 2000). Moreover, despite people's claimed commitment to sacred values, they still violate them when doing so is strategic or justifiable, leading Tetlock (2003) to refer to such values as "pseudo-sacred" (see also Tetlock et al., 2020; Thompson and Gonzalez, 1997).

Second, the entities that people treat as sacred are those that seem most important for garnering trust. Sacred values include symbols of the group and resources that groups collectively defend or fight for, such as land (Dumper, 2002; Ginges et al., 2007). Never violating these values should indicate one's consistent commitment to shared group objectives, attracting the trust of followers, co-combatants, or others invested in the group's success. Other sacred values include a politician's ideological platform (Marietta, 2008), which attracts the trust of voters who favor that position, and, among modern Westerners, human life or a revulsion towards monetizing body parts (Tetlock et al., 2000; S. Wilkinson \& Garrard, 1996), which assure others that the actor will never harm them. In many societies, people treat a repulsion to cannibalism as 


\section{COMMITMENT AND IMPERSONATION}

sacred (e.g., Comanche: Wallace and Hoebel, 1952; !Kung: Marshall, 1962; Malays: Peletz, 1988; see also regularities in witch accusations: Singh, in press). Even thinking about eating another in-group member is among the vilest acts possible, leading some peoples to taboo animals that even loosely resemble humans (e.g., Konso: Hallpike, 1972; Warao: Wilbert, 1972). This makes sense within the proposed framework. Someone who would even consider eating human flesh is not to be trusted, given that they might transmit pathogens or, much more pressingly, attack one when they can get away with it.

Extreme self-sacrifice does not invalidate a trust management explanation.

Atran and colleagues have argued that sacredness cannot be explained as a form of "posturing" (Atran et al., 2005; Atran \& Axelrod, 2008; Atran \& Medin, 2008), pointing to the tendency for people like suicide terrorists to engage in extreme, self-sacrificial behavior for their purported ideals (Atran, 2003; Ginges et al., 2009). But there are three ways in which self-sacrifice is consistent with our account.

First, our argument is not that principled behavior is always optimal. Rather, we claim that ultimate function of acting principled is to garner trust. Yes, we expect that people will adopt different principles and vary in how principled they act depending on the social settingthat is, we expect the psychological mechanics underlying principledness to be sufficiently flexible to respond to costs and benefits-but we also expect errors. When people are highly reliant on others' trust, and others favor individuals who will die for the group, it might be cognitively efficient to treat dying for the group as a moral imperative, precluding the actor from considering other options and resulting in self-sacrifice (see, e.g., Berns et al. 2012; Phillips and Cushman 2017). Just as people prefer pornography and chocolate cake, the mechanisms underlying principledness may be ultimately adaptive but prone to maladaptive outcomes.

Second, people might engage in self-sacrifice for reasons distinct from their ideological commitment (Klonsky et al., 2016). They might suffer from psychiatric illness (Lankford 2014; although see Atran 2014) or use suicidal behavior for interpersonal bargaining or to lessen a burden on their families (Syme et al., 2016). Or, as is more likely, the glory of martyrdom may be so enticing that people are willing to die for it (Sageman, 2008). When people who kill themselves for the group are celebrated, people seeking prestige may be motivated to follow them. ${ }^{8}$ People may kill themselves for reasons distinct from sacred values, claiming principles to either enhance their reputation or justify suicidal goals.

Third, people who engage in self-sacrifice might be genuinely committed. They might actually have the trustworthy belief or incentive structures that other people claim: They might, for example, sincerely believe in supernatural rewards for martyrs or they may be undyingly devoted to the group's success in intergroup conflict, no matter the costs. In that case, these rare committed agents would be the models that all the other principled actors are impersonating.

Regardless of whether (1) the mechanics of garnering trust can lead to self-sacrifice, (2) people kill themselves for glory or because of mental illness and then re-frame it as ideological, or (3) a few people sincerely believe in material benefits or are committed to group-beneficial aims,

\footnotetext{
${ }^{8}$ Again, this behavior might not be adaptive in the setting but rather the outcome of motivational systems designed to reap usually adaptive ends, such as fame.
} 


\section{COMMITMENT AND IMPERSONATION}

extreme self-sacrifice is incredibly rare and is consistent with an account in which principled behavior is overwhelmingly deployed for strategic ends.

\section{Explaining relational versus universalist principles}

Perhaps the best-documented variation in principles is modern Westerners' commitment to universalist ethics, a set of principles that is historically and cross-culturally peculiar (Henrich, 2020; Pinker, 2011; Snarey, 1985). Kohlberg (1981) regarded these principles as the pinnacle of moral reasoning. Snarey (1985) summarized them as follows:

Following self-chosen ethical principles; particular laws or social agreements are usually valid because they rest on such principles; when laws violate these principles, one acts in accordance with the principle; principles are universal principles of justice: the equality of human rights and respect for the dignity of human beings as individual persons; the reason for doing right is the belief, as a rational person, in the validity of universal moral principles and a sense of personal commitment to them

The ideas at the core of this morality are (1) moral principles trump society's laws; (2) all humans should be treated equally; (3) individuals and their bodies are inviolable; and (4) reason and rationality are the foundation for holding particular moral principles. Similar ideas are expressed in the United Nations' Universal Declaration of Human Rights (UN General Assembly, 1948) and even the 7 tenets of the modern Satanic Temple (The Satanic Temple, 2020).

These principles differ from those that people have endorsed for most of human history. Other societies have valued duty, loyalty to friends, loyalty to kin, obedience to law, religious piousness, and commitment to a coalition, among other values. In the Bhagavad Gita, an ancient Sanskrit scripture and a section of the Hindu epic Mababarata, the god Krishna explains at length that one should abide by one's dharma, or moral duty, beyond any selfish and material incentives (Easwaran, 2007). One's duty varies according to where one is situated in a social hierarchy; for a warrior, living dutifully means engaging in righteous wars, even if this means killing family and friends. When, in 1905, Erdland (1914/1961) saw that the people of the Marshall Islands gathered around the chief's hut to protect it from being torn away by a hurricane, he asked a person why they didn't seek shelter with European merchants. "You Whites may die with your governor," they replied (perhaps mistakenly projecting their own principles onto Erdland), "We shall die with our chief" (p. 81). Malays prioritized loyalty to one's family, village, and chief. They summarized how people should value these ends even when unappealing in proverbs like, "Though it rain silver and gold abroad, though it rain daggers and spears at home-still, home is the better" and "When the tree falls, the woodpeekers [sic] that live on it must also perish," the latter meaning that a person's interests ultimately rely on the welfare of their chief (Wilkinson 1925, pp. 10-11). Relational moral principles still persist in the contemporary West (Graham et al., 2009; Haidt, 2012), yet they are far less dominant than they have been for most human history (Henrich, 2020).

What explains Westerners' shift to universal moral principles? Kohlberg (1981) saw universalist principles as the pinnacle of moral reasoning. Pinker (2011) regarded them as the 


\section{COMMITMENT AND IMPERSONATION}

results of, among other factors, a widening circle of empathy and enhanced reasoning abilities driven by the Flynn effect.

Our account, in contrast, predicts that moral principles vary throughout history and across societies because the costs and benefits of conforming to those principles varies (see also Henrich, 2020; Rai \& Fiske, 2011). Compare a principle of loyalty to a principle of universal harm reduction. Abiding by each of them may appear to make a party more trustworthy, although how trustworthy varies with the social environment. In a society where people rely on long-term relationships for deterrence and risk management, parties devoted to loyalty should be more appealing cooperation partners than parties who care about universal ethics. A party who values loyalty can be trusted to help deter violence and share resources in tough times; a party who cares about universally reducing suffering might help people they don't know at the expense of their reciprocity partners. Meanwhile, abiding by each of these principles carries costs, although again, the magnitude differs. In a society where people rely on each other for mutual protection, loyalty gets one entangled in friends' ongoing feuds, yet universalist ethics may prevent one from attacking back in the first place. Relational moral principles are crucial in societies in which people rely on long-term relationships to secure services such as risk management and protection. In contrast, universalist moral principles become useful as societies become anonymized and services are provided by impersonal institutions.

Several lines of evidence support the claim that universalist principles replace relational ones as the payoffs of claiming them shift. First, historical figures have had difficulty promoting universalist principles in ecologies that favor relational ones. Take the Chinese philosopher Mozi, who argued for a principle of impartial love (Mei, 1973). Many other Chinese thinkers found such a principle unappealing, because it denied one's special relationships with friends, family, and the state (Van Norden, 2007). As the Confusion philosopher Menzi replied, impartial love "is to not have a father. To not have a father... is to be an animal" (cited in Van Norden, 2007, p. 199). Moreover, when a later follower of Mozi, Yi Zhi, was branded hypocritical for giving his parents a lavish burial, he tried to refashion Mozi's universalism into a form that permitted partiality towards kin. As long as universal principles are distrusted or one's behavior is difficult to justify with them, people should prefer relational principles.

Second, universal principles seem to have emerged in communities where people benefit most from being seen as generally impartial: impersonal markets. In markets where strangers freely interact, people benefit from appearing committed to cooperation with anonymous others (Henrich, 2020). Not only does market integration predict greater impartial prosociality (Henrich, Ensminger, et al., 2010; Tu and Bulte, 2010; although see Siziba and Bulte, 2012)and not only was mercantile law long characterized by a greater degree of universality, being more general and less discriminatory, than other legal traditions (Berman, 1983) — but the rise of universalist virtues is historically tied to the growth of free markets in northwestern Europe (McCloskey, 2016; Russell, 1972). People began to claim principles of impartial prosociality when the social ecology favored them.

Rights are expanding partly because people are motivated to behave consistently with universalist principles

Our account also helps explain why various rights and privileges have become increasingly inclusive - why, for instance, racial and sexual minorities are enjoying rights previously restricted 


\section{COMMITMENT AND IMPERSONATION}

to land-owning white men. Insofar as some groups enjoy privileges that others do not and rulemaking leaders claim to abide by universalist principles, people can challenge the leaders on their hypocrisy and force institutional change. Leaders who need to seem consistent and who lack other justifications will be motivated to concede.

According to historians, the reputational costs of hypocrisy contributed to the civil rights movement in the United States (Dudziak, 2000; Skrentny, 1998). During the Cold War, the U.S. and the Soviet Union competed to draw "Third World countries", many of them nonwhite, into their respective spheres of influence. Although the U.S. claimed a commitment to universal human rights, it was often branded a hypocrite for its racist, homeland policies. These reputational costs were among the factors that pushed policy makers to confer rights to minorities, a point communicated in the following letter from the U.S. Secretary of State, Dean Acheson, written in 1946 and released by the President's Committee on Civil Rights (1947):

We are reminded over and over by some foreign newspapers and spokesmen, that our treatment of various minorities leaves much to be desired... Frequently we find it next to impossible to formulate a satisfactory answer to our critics in other countries; the gap between the things we stand for in principle and the facts of a particular situation may be too wide to be bridged. An atmosphere of suspicion and resentment in a country over the way a minority is being treated in the United States is a formidable obstacle to the development of mutual understanding and trust between the two countries. We will have better international relations when these reasons for suspicion and resentment have been removed.

I think that it is quite obvious...that the existence of discriminations against minority groups in the United States is a handicap in our relations with other countries. The Department of State, therefore, has good reasons to hope for the continued and increased effectiveness of public and private efforts to do away with these discriminations.

The expansion of inclusive rights occurs in domains aside from civil rights, as well. Volokh (2003) documented a case of "equality-based slippage" in euthanasia laws in the Netherlands. Dutch courts started by allowing doctors to assist the suicides of terminally ill patients. After a series of challenges, they then extended these protections to victims of physical "unbearable suffering", and then to a patient whose chronic depression, alcohol abuse, and prescription drug abuse caused mental illness "subjectively experienced as unbearable", and then to a woman who suffered emotional pain after her two children died. At the time Volokh wrote about the slippage, he described a Dutch doctor who argued that "people should be able to commit assisted suicide simply to avoid burdening their families, just like they may commit assisted suicide to avoid unbearable suffering. There is no principled way, the doctor reasoned, to distinguish [the two]" (Volokh, 2003, p. 1063). From civil rights to euthanasia, rules will become inclusive when rule-makers claim universalist principles and lack alternative justifications to keep them unequal.

We suspect that a similar dynamic underlies some of the arguments for becoming a vegan presented at the outset of this paper. As people claim to be both committed to reducing suffering and universalist in their ethics, they appear inconsistent if they knowingly perpetuate suffering by eating animals or their products. This is the rhetorical aim of Peter Singer's (2002) influential book Animal Liberation. He set out, he admitted, to show that "there can be no reason-except 


\section{COMMITMENT AND IMPERSONATION}

the selfish desire to preserve the privileges of the exploiting group-for refusing to extend the principle of equality of consideration to members of other species" (p. xxiii). According to his argument, a person is a hypocrite if they subscribe to both "the principle of equality of consideration" and the moral axiom of reducing suffering yet continue to perpetuate suffering on animals. Such individuals foster a "form of prejudice no less objectionable than prejudice about a person's race or sex” (Singer, 2002, p. xxiii). The book's lasting impact and influence (e.g., Villanueva, 2016) suggest that its rhetorical strategy was effective at persuading people to adopt vegetarianism, providing further evidence that our moral circle expands as we struggle to behave consistently with universalist principles.

\section{Explaining supernatural punishment beliefs}

Everywhere, humans claim to believe in supernatural forces that reward good behavior and punish bad behavior (Boehm, 2008; Pew Research Center, 2017; Purzycki et al., 2020). Some scholars argue that these beliefs guide people's behavior as they intuitively and sincerely believe that omniscient third parties monitor their behavior (Norenzayan, 2013; Norenzayan et al., 2016). Here we argue that at least some religious belief is a proximate motivation for principled behavior-an internalized belief structure that people enact (not necessarily consciously) to convince others that they are trustworthy.

Several lines of evidence suggest that prosocial religious belief is an example of principled behavior. First, religious people are trusted more (Edgell et al., 2006; Gervais, 2013; Gervais et al., 2017; Tan \& Vogel, 2008). In one of the many studies on the topic, Gervais et al. (2011) told undergraduates that a man, Richard, hit a parked car, drove away without leaving his information, and then stole money from a wallet on the sidewalk before throwing the wallet in the trash. In a between-subjects design, students thought it equally probable that Richard was an atheist and a rapist, and unlikely he was a Christian or Muslim. As a Kazakh proverb taught, "Fear him who does not fear God, but do not fear him who fears God" (Grodekov, 2010, p. 239).

Second, people benefit from masquerading as religious, and from what it looks like, they often do. In representative telephone polls, $3 \%$ of Americans self-identify as atheists (Pew Research Center, 2015) and 12\% answer "No" to the question "Do you believe in God?" (Gallup, 2017). Yet using the unmatched count technique, a tool for detecting base rates of socially sensitive outcomes, Gervais and Najle (2018) found that "roughly one in four (26\%) of American adults may be atheists-2.4-8.7 times as many as telephone polls" (p. 8) (see also Hadaway et al. 1993).

Gervais and Najle measured explicit belief: People answered either that they believed in god or did not. But it's also likely that that many people sincerely feel that they believe in god, while that belief is internalized by cognitive mechanisms functioning to attract trust. Suggestive evidence comes from a meta-analysis by Sedikides and Gebauer (2010), who tested whether people use intrinsic religiosity for self-enhancement. Intrinsic religiosity is "freely chosen and endorsed by the believers and is central to their lives as an end in itself" (p. 20) and is captured by scale items such as "I try hard to live my life according to my religious beliefs" and "My whole approach to life is based on religion". Across 30 samples $(\mathrm{N}=5,016)$, and taking into account a file-drawer effect, they found strong evidence for a relationship between socially desirable responding and intrinsic religiosity $\left(\mathrm{r}_{\text {orig }}=0.163, \mathrm{r}_{\mathrm{adj}}=0.129, \mathrm{p} \leq 0.0001\right)$. Notably, this effect was 


\section{COMMITMENT AND IMPERSONATION}

strongest in environments where religiosity is most important (United States $>$ Canada $>$ United Kingdom; Christian universities > secular universities). Consciously or not, people seem to perform religiosity to enjoy the social benefits.

Third, the religious moral sphere seems to track the cooperative sphere (Wright, 2009). We argued that people's principles should vary with the social ecology. In societies where people rely on long-term relationships for services like protection and risk management, they should abide by parochial principles, such as loyalty. Meanwhile, in societies where people interact with many anonymous partners and have shallower relationships, they should abide by more universalist principles. Religious belief seems to track this variation (Peoples \& Marlowe, 2012; Roes \& Raymond, 2003; Singh et al., 2021; Swanson, 1964; Watts et al., 2015; Wright, 2009).

If people enact beliefs in supernatural punishment to attract trust, then we predict that believers will respond to payoffs similarly just as other principled people do. For example, if people perform religious belief for reputational benefits, they should engage in religious behavior more as the risk of being seen as non-religious increases (Figure 2). And not only should a believer suffer a dramatic loss of trust after performing an unambiguous breach (Figure 1), but following that loss of trust, they should be less motivated to engage in apparently religiously inspired behaviors. Future research should evaluate whether these and the other predictions listed in Table 1 apply to people with beliefs in moralistic supernatural beliefs.

\section{Summary}

We humans are complicated. We cheat, scheme, learn, deceive, and analyze. We have second thoughts, balance costs and benefits, and are subject to self-interested, automatic biases. Principled behavior seems to defy all of this. The principled actor is devoted rather than strategic. They are simple rather than calculating. They are predictable and therefore dependable. Yet appearances can be deceiving. Principled behavior does not violate strategic behavior; it exemplifies it. Principled behavior is, for the most part, an internalized performance of a trustworthy psychology, affected to reap social benefits. It is a demonstration of cognitive flexibility rather than rigidness, of our (non-conscious) capacity to evaluate the payoffs of different appearances and tactically deploy them. For many people, principled behavior is just another way to win friends and influence others. 


\section{COMMITMENT AND IMPERSONATION}

\section{Literature cited}

Aaker, J., Fournier, S., \& Brasel, S. A. (2004). When Good Brands Do Bad. Journal of Consumer Research, 31(1), 1-16. https://doi.org/10.1086/383419

Allgeier, A. R., Byrne, D., Brooks, B., \& Revnes, D. (1979). The Waffle Phenomenon: Negative Evaluations of Those Who Shift Attitudinally. Journal of Applied Social Psychology, 9(2), 170-182. https://doi.org/10.1111/j.1559-1816.1979.tb00802.x

Andreottola, G. (2018). Flip-flopping and Electoral Concerns.

Aronson, E. (1969). The theory of cognitive dissonance: A current perspective. In Advances in experimental social psychology (pp. 1-34). Academic Press.

Aronson, E. (1992). The return of the repressed: Dissonance theory makes a comeback. Psychological Inquiry, 3(4), 303-311.

Aronson, E., Fried, C., \& Stone, J. (1991). Overcoming denial and increasing the intention to use condoms through the induction of hypocrisy. American Journal of Public Health, 81(12), 1636-1638. https://doi.org/10.2105/AJPH.81.12.1636

Asch, S. E. (1946). Forming Impressions of Personality. The Journal of Abnormal and Social Psychology, 41(3), 258-290. https://doi.org/10.1111/j.1467-6494.1954.tb02338.x

Ashmore, R. D., \& Collins, B. E. (1968). Studies in forced compliance: X. Attitude change and commitment to maintain publicly a counterattitudinal position. Psychological Reports, 22, $1229-1234$.

Atran, S. (2003). Genesis of suicide terrorism. Science, 299(5612), 1534-1539. https://doi.org/10.1126/science.1078854

Atran, S. (2014). Martyrdom's would-be myth buster. Behavioral and Brain Science, 37, 362-363.

Atran, S. (2016). The devoted actor: Unconditional commitment and intractable conflict across cultures. Current Antbropology, 57(S13), S192-S203. https://doi.org/10.1086/685495

Atran, S., \& Axelrod, R. (2008). Reframing sacred values. Negotiation Journal, 221-246.

Atran, S., \& Henrich, J. (2010). The evolution of religion: How cognitive by-products, adaptive learning heuristics, ritual displays, and group competition generate deep commitments to prosocial religions. Biological Theory, 5, 18-30. http://hal-ens.archivesouvertes.fr/ijn_00505193/

Atran, S., \& Medin, D. (2008). The native mind and the cultural construction of nature. MIT Press.

Atran, S., Medin, D. L., \& Ross, N. O. (2005). The cultural mind: Environmental decision making and cultural modeling within and across populations. Psychological Review, 112(4), 744-776. https://doi.org/10.1037/0033-295X.112.4.744

Banerjee, M. (2007). Sacred elections. Economic and Political Weekly, 42(17), 1556-1562.

Barclay, P. (2013). Strategies for cooperation in biological markets, especially for humans. Evolution and Human Behavior, 34(3), 164-175.

https://doi.org/10.1016/j.evolhumbehav.2013.02.002

Baron, J., \& Leshner, S. (2000). How serious are expressions of protected values? Journal of Experimental Psychology: Applied, 6(3), 183-194. https://doi.org/10.1037/1076898X.6.3.183

Baron, J., \& Spranca, M. (1997). Protected values. Organizational Behavior and Human Decision Processes, 70(1), 1-16. https://doi.org/10.1006/obhd.1997.2690 


\section{COMMITMENT AND IMPERSONATION}

Barrett, H. C. (2015). The shape of thought: How mental adaptations evolve. Oxford University Press.

Baumard, N., André, J.-B., \& Sperber, D. (2013). A mutualistic approach to morality: the evolution of fairness by partner choice. Behavioral and Brain Sciences, 36(1), 59-78. https://doi.org/10.1017/S0140525X11002202

Baumeister, R. F. (1982). A self-presentational view of social phenomena. Psychological Bulletin, 91(1), 3-26. https://doi.org/10.1037/0033-2909.91.1.3

Beaman, A. L., Cole, C. M., Preston, M., Klentz, B., \& Steblay, N. M. (1983). Fifteen years of foot-in-the-door research: A meta-analysis. Personality and Social Psychology Bulletin, 9(2), 181-196. https://doi.org/10.1177/0146167283092002

Bell, A. V, Richerson, P. J., \& McElreath, R. (2009). Culture rather than genes provides greater scope for the evolution of large-scale human prosociality. Proceedings of the National Academy of Sciences of the United States of America, 106(42), 17671-17674. https://doi.org/10.1073/pnas.0903232106

Bem, D. J. (1967). Self-Perception: an Alternative Interpretation of Cognitive Dissonance Phenomena. Psychological Review, 74(3), 183-200. https://doi.org/10.1037/h0024835

Bénabou, R., \& Tirole, J. (2006). Incentives and prosocial behavior. American Economic Review, 96(5), 1652-1678. https://doi.org/10.1257/aer.96.5.1652

Benedict, R. (1947). The chrysanthemum and the sword: Patterns of Japanese culture. Secker \& Warburg. https://archive.org/details/in.ernet.dli.2015.77454/page/n5/mode/2up

Bennis, W. M., Medin, D. L., \& Bartels, D. M. (2010). The costs and benefits of calculation and moral rules. Perspectives on Psychological Science, 5(2), 187-202.

https://doi.org/10.1177/1745691610362354

Berman, H. J. (1983). Law and revolution: The formation of the Western legal tradition. Harvard University Press.

Berns, G. S., Bell, E., Capra, C. M., Prietula, M. J., Moore, S., Anderson, B., Ginges, J., \& Atran, S. (2012). The price of your soul: Neural evidence for the non-utilitarian representation of sacred values. Philosophical Transactions of the Royal Society B: Biological Sciences, 367(1589), 754-762. https://doi.org/10.1098/rstb.2011.0262

Bhatti, Y., Hansen, K. M., \& Olsen, A. L. (2013). Political hypocrisy: The effect of political scandals on candidate evaluations. Acta Politica, 48(4), 408-428. https://doi.org/10.1057/ap.2013.6

Blanken, I., van de Ven, N., \& Zeelenberg, M. (2015). A Meta-Analytic Review of Moral Licensing. Personality and Social Psychology Bulletin, 41(4), 540-558. https://doi.org/10.1177/0146167215572134

Bliege Bird, R., \& Smith, E. A. (2005). Signaling Theory, Strategic Interaction, and Symbolic Capital. Current Anthropology, 46(2), 221-248. https://doi.org/10.1086/427115

Boehm, C. (1984). Blood revenge: The anthropology of feuding in Montenegro and other tribal societies. University Press of Kansas.

Boehm, C. (2008). A biocultural evolutionary exploration of supernatural sanctioning. In J. Bulbulia, R. Sosis, E. Harris, R. Genet, C. Genet, \& K. Wyman (Eds.), Evolution of religion: Studies, theories, and critiques (pp. 143-152). Collins Foundation Press.

Bohannan, P. (1968). Justice and judgment among the Tiv. Oxford University Press for the International African Institute.

Boyd, R. (2017). A different kind of animal: How culture transformed our species. Princeton 


\section{COMMITMENT AND IMPERSONATION}

University Press.

Brown, R. P., Tamborski, M., Wang, X., Barnes, C. D., Mumford, M. D., Connelly, S., \& Devenport, L. D. (2011). Moral credentialing and the rationalization of misconduct. Ethics and Behavior, 21(1), 1-12. https://doi.org/10.1080/10508422.2011.537566

Burger, J. M. (1999). The foot-in-the-door compliance procedure: A multiple-process analysis and review. Personality and Social Psychology Review, 3(4), 303-325.

https://doi.org/10.1207/s15327957pspr0304_2

Burnstein, E., Crandall, C., \& Kitayama, S. (1994). Some Neo-Darwinian Decision Rules for Altruism: Weighing Cues for Inclusive Fitness as a Function of the Biological Importance of the Decision. Journal of Personality and Social Psychology, 67(5), 773-789. https://doi.org/10.1037/0022-3514.67.5.773

Cabrales, A., Espín, A. M., Kujal, P., \& Rassenti, S. (2017). Humans' (incorrect) distrust of reflective decisions. $S S R N$. https://papers.ssrn.com/sol3/papers.cfm?abstract_id=2938434

Capraro, V., \& Kuilder, J. (2016). To know or not to know? Looking at payoffs signals selfish behavior, but it does not actually mean so. Journal of Behavioral and Experimental Economics, 65, 79-84. https://doi.org/10.1016/j.socec.2016.08.005

Carlos, W. C., \& Lewis, B. W. (2018). Strategic Silence: Withholding Certification Status as a Hypocrisy Avoidance Tactic. In Administrative Science Quarterly (Vol. 63, Issue 1). https://doi.org/10.1177/0001839217695089

Carlson, J. M., \& Dolan, K. (1985). The waffle phenomenon and candidates' image. Psychological Reports, 57, 795-798.

Cerulli, E. (1959). Observations on the Moslem movement in Somaliland. Human Relations Area Files.

Chanley, V., Sullivan, J. L., Gonzales, M. H., \& Kovera, M. B. (1994). Lust and avarice in politics: Damage control by four politicians accused of wrongdoing (or, politics as usual). American Politics Research, 22(3), 297-333. https://doi.org/10.1177/1532673X9402200303

Choi, I., Nisbett, R. E., \& Norenzayan, A. (1999). Causal Attribution Across Cultures: Variation and Universality. Psychological Bulletin, 125(1), 47-63. https://doi.org/10.1037/0033-2909.125.1.47

Chua, T. H. H., \& Chang, L. (2016). Follow me and like my beautiful selfies: Singapore teenage girls' engagement in self-presentation and peer comparison on social media. Computers in Human Behavior, 55, 190-197. https://doi.org/10.1016/j.chb.2015.09.011

Clot, S., Grolleau, G., \& Ibanez, L. (2013). Self-licensing and financial rewards: Is morality for sale? Economics Bulletin, 33(3), 2298-2306.

Collani, G. Von. (2003). Being together in a situation of induced hypocrisy. Current Research in Social Psychology, 13(12), 145-153.

http://www.uiowa.edu/ grpproc/crisp/crisp13_12.pdf\%5Cnhttp://www.psycontent.com/in dex/01413HX7R0538441.pdf

Collocott, E. E. V. (1922). Proverbial sayings of the Tongans. Bishop Museum Press.

Colquitt, J. A., Scott, B. A., \& LePine, J. A. (2007). Trust, Trustworthiness, and Trust

Propensity: A Meta-Analytic Test of Their Unique Relationships With Risk Taking and

Job Performance. Journal of Applied Psychology, 92(4), 909-927.

https://doi.org/10.1037/0021-9010.92.4.909

Cooper, J. (2007). Cognitive dissonance: Fifty years of a classic theory. Sage Publications.

Cooper, J., \& Fazio, R. H. (1984). A new look at dissonance theory. In L. Berkowitz (Ed.), 


\section{COMMITMENT AND IMPERSONATION}

Advances in experimental social psychology, vol. 17 (pp. 229-266). Academic Press.

Critcher, C. R., Inbar, Y., \& Pizarro, D. a. (2012). How Quick Decisions Illuminate Moral Character. Social Psychological and Personality Science, 4(3), 308-315. https://doi.org/10.1177/1948550612457688

Cronk, L. (1994). Evolutionary theories of morality and the manipulative use of signals. Zygon, 29(1), 81-102.

Cross, S. E., Gore, J. S., \& Morris, M. L. (2003). The Relational-Interdependent SelfConstrual, Self-Concept Consistency, and Well-Being. Journal of Personality and Social Psychology, 85(5), 933-944. https://doi.org/10.1037/0022-3514.85.5.933

Crotty, W. J. (1967). Democratic consensual norms and the college student. Sociology of Education, 40(3), 200-218.

Cullum, J., \& Harton, H. C. (2007). Cultural evolution: Interpersonal influence, issue importance, and the development of shared attitudes in college residence Halls. Personality and Social Psychology Bulletin, 33(10), 1327-1339.

https://doi.org/10.1177/0146167207303949

Curran, T., Hill, A. P., Appleton, P. R., Vallerand, R. J., \& Standage, M. (2015). The psychology of passion: A meta-analytical review of a decade of research on intrapersonal outcomes. Motivation and Emotion, 39(5), 631-655. https://doi.org/10.1007/s11031-0159503-0

Darwin, C. (1871). The Descent of Man, and Selection in Relation to Sex. J. Murray.

Davis, A. L., \& Rothstein, H. R. (2006). The effects of the perceived behavioral integrity of managers on employee attitudes: A meta-analysis. Journal of Business Ethics, 67(4), 407-419. https://doi.org/10.1007/s10551-006-9034-4

Davis, J. L., \& Rusbult, C. E. (2001). Attitude alignment in close relationships. Journal of Personality and Social Psychology, 81(1), 65-84.

de Aguiar, R., \& Cronk, L. (2011). Stratification and supernatural punishment: cooperation or obedience? Religion, Brain, E' Behavior, 1(1), 73-75.

Dehghani, M., Atran, S., Iliev, R., Sachdeva, S., Medin, D., \& Ginges, J. (2010). Sacred values and conflict over Iran's nuclear program. Judgment and Decision Making, 5(7), 540-546.

Dehghani, M., Iliev, R., Sachdeva, S., Atran, S., Ginges, J., \& Medin, D. (2009). Emerging sacred values: Iran's nuclear program. Judgment and Decision Making, 4, 990-993.

Devine, P. G., Tauer, J. M., Barron, K. E., Elliot, A. J., \& Vance, K. M. (1999). Moving beyond attitude change in the study of dissonance-related processes. Cognitive Dissonance: Progress on a Pivotal Theory in Social Psychology, 297-323. https://doi.org/10.1037/10318012

Dezecache, G., Mercier, H., \& Scott-Phillips, T. C. (2013). An evolutionary approach to emotional communication. Journal of Pragmatics, 59, 221-233. https://doi.org/10.1016/j.pragma.2013.06.007

Dickerson, C. A., Thibodeau, R., Aronson, E., \& Miller, D. (1992). Using Cognitive Dissonance to Encourage Water Conservation. Journal of Applied Social Psychology, 22(11), 841-854. https://doi.org/10.1111/j.1559-1816.1992.tb00928.x

Dineen, B. R., Lewicki, R. J., \& Tomlinson, E. C. (2006). Supervisory guidance and behavioral integrity: Relationships with employee citizenship and deviant behavior. Journal of Applied Psychology, 91(3), 622-635. https://doi.org/10.1037/0021-9010.91.3.622

Doherty, D., Dowling, C. M., \& Miller, M. G. (2016). When is changing policy positions costly 


\section{COMMITMENT AND IMPERSONATION}

for politicians? Experimental evidence. Political Behavior, 38(2), 455-484.

https://doi.org/10.1007/s11109-015-9321-9

Donahue, E. M., Robins, R. W., Roberts, B. W., \& John, O. P. (1993). The Divided Self:

Concurrent and Longitudinal Effects of Psychological Adjustment and Social Roles on

Self-Concept Differentiation. Journal of Personality and Social Psychology, 64(5), 834-846.

https://doi.org/10.1037/0022-3514.64.5.834

Dudziak, M. L. (2000). Cold War civil rights: Race and the image of American democracy. Princeton University Press.

Dumper, M. (2002). The politics of sacred space: The old city of Jerusalem in the Middle East conflict. Lynne Rienner Publishers.

Easwaran, E. (2007). The Bhagavad Gita.

Edgell, P., Gerteis, J., \& Hartmann, D. (2006). Atheists as "other": Moral boundaries and cultural membership in American society. American Sociological Review, 71, 211-234.

Effron, D. A., Cameron, J. S., \& Monin, B. (2009). Endorsing Obama licenses favoring Whites. Journal of Experimental Social Psychology, 45(3), 590-593.

https://doi.org/10.1016/j.jesp.2009.02.001

Effron, D. A., Markus, H. R., Jackman, L. M., Muramoto, Y., \& Muluk, H. (2018). Hypocrisy and culture: Failing to practice what you preach receives harsher interpersonal reactions in independent (vs. interdependent) cultures. Journal of Experimental Social Psychology, 76(February), 371-384. https://doi.org/10.1016/j.jesp.2017.12.009

Effron, D. A., \& Monin, B. (2010). Letting people off the hook: When do good deeds excuse transgressions? Personality and Social Psychology Bulletin, 36(12), 1618-1634. https://doi.org/10.1177/0146167210385922

Effron, D. A., O’Connor, K., Leroy, H., \& Lucas, B. J. (2018). From inconsistency to hypocrisy: When does "saying one thing but doing another" invite condemnation? Research in Organizational Behavior, 38, 61-75. https://doi.org/10.1016/j.riob.2018.10.003

Eisenbruch, A. B., Grillot, R. L., Maestripieri, D., \& Roney, J. R. (2016). Evidence of partner choice heuristics in a one-shot bargaining game. Evolution and Human Behavior, 37(6), 429-439. https://doi.org/10.1016/j.evolhumbehav.2016.04.002

Engelmann, J. M., Herrmann, E., \& Tomasello, M. (2012). Five-Year Olds, but Not Chimpanzees, Attempt to Manage Their Reputations. PLoS ONE, 7(10). https://doi.org/10.1371/journal.pone.0048433

Enli, G. (2015). “Trust Me, I am authentic!": Authenticity Illusions in social media politics. In A. Bruns, G. Enli, E. Skogerbo, A. O. Larsson, \& C. Christensen (Eds.), The Routledge Companion to Social Media and Politics (pp. 121-136). Taylor \& Francis. https://doi.org/10.4324/9781315716299

Enoch, Y. (1989). Change of values during socialization for a profession: An application of the marginal man theory. Human Relations, 42, 219-239.

Erdland, A. (1961). The Marshall Islanders: Life and customs, thought and religion of a South Seas people. Human Relations Area Files.

Everett, J. A. C., Pizarro, D. A., \& Crockett, M. J. (2016). Inference of trustworthiness from intuitive moral judgments. Journal of Experimental Psychology: General, 145(6), 772-787. https://doi.org/10.1037/xge0000165

Faulkingham, R. H. (1971). Political support in a Hausa village. Michigan State University.

Fehrler, S., \& Przepiorka, W. (2013). Charitable giving as a signal of trustworthiness: 


\section{COMMITMENT AND IMPERSONATION}

Disentangling the signaling benefits of altruistic acts. Evolution and Human Behavior, 34(2), 139-145. https://doi.org/10.1016/j.evolhumbehav.2012.11.005

Festinger, L. (1957). A theory of cognitive dissonance. Stanford University Press.

Festinger, L., \& Carlsmith, J. M. (1959). Cognitive consequences of forced compliance. Journal of Abnormal and Social Psychology, 58(2), 203-210. https://doi.org/10.1037/h0041593

Frank, R. H. (1988). Passions within reason: The strategic role of the emotions. W. W. Norton \& Company.

Freeman, P. (2011). Alexander the Great. Simon \& Schuster.

Fried, C. B. (1998). Hypocrisy and identification with transgressions: A case of undetected dissonance. Basic and Applied Social Psychology, 144-154.

Fudenberg, D., \& Levine, D. K. (1989). Reputation and equilibrium selection in games with a patient player. Econometrica, 57(4), 759-778.

Fudenberg, D., \& Maskin, E. (1986). The folk theorem in repeated games with discounting or with incomplete information. Econometrica, 54(3), 533-554.

Gallup. (2017). Religion. https://news.gallup.com/poll/1690/Religion.aspx

Gawronski, B. (2012). Back to the future of dissonance theory: Cognitive consistency as a core motive. Social Cognition, 30(6), 652-668. https://doi.org/10.1521/soco.2012.30.6.652

Gelfand, M. (1967). The African witch: With particular references to witchcraft beliefs and practices among the Shona of Rhodesia. E. \& S. Livingstone.

Gershman, S. J. (2019). How to never be wrong. Psychonomic Bulletin and Review, 26(1), 13-28. https://doi.org/10.3758/s13423-018-1488-8

Gervais, W. M. (2013). In godlessness we distrust: Using social psychology to solve the puzzle of anti-atheist prejudice. Social and Personality Psychology Compass, 6, 366-377.

Gervais, W. M., \& Najle, M. B. (2018). How Many Atheists Are There? Social Psychological and Personality Science, 9(1), 3-10. https://doi.org/10.1177/1948550617707015

Gervais, W. M., Shariff, A. F., \& Norenzayan, A. (2011). Do you believe in atheists? Distrust is central to anti-atheist prejudice. Journal of Personality and Social Psychology, 101(6), 11891206. https://doi.org/10.1037/a0025882

Gervais, W. M., Xygalatas, D., McKay, R. T., Van Elk, M., Buchtel, E. E., Aveyard, M., Schiavone, S. R., Dar-Nimrod, I., Svedholm-Häkkinen, A. M., Riekki, T., Klocová, E. K., Ramsay, J. E., \& Bulbulia, J. (2017). Global evidence of extreme intuitive moral prejudice against atheists. Nature Human Behaviour, 1(8), 1-6. https://doi.org/10.1038/s41562-0170151

Gigerenzer, G. (2008). Moral intuition = fast and frugal heuristics? In W. Sinnott-Armstrong (Ed.), Moral psychology: The cognitive science of morality: Intuition and diversity (vol. 2). MIT Press.

Gilbert, D. T. (1998). Ordinary personology. In The Handbook of Social Psychology (pp. 89-150).

Ginges, J., \& Atran, S. (2009). Noninstrumental reasoning over sacred values: An Indonesian case study. Psychology of Learning and Motivation, 50, 193-206.

https://doi.org/10.1016/S0079-7421(08)00406-4

Ginges, J., \& Atran, S. (2011). War as a moral imperative (not just practical politics by other means). Proceedings of the Royal Society B: Biological Sciences, 278(1720), 2930-2938. https://doi.org/10.1098/rspb.2010.2384

Ginges, J., \& Atran, S. (2015). Sacred Values and Cultural Conflict. In Advances in Culture and Psychology (pp. 273-301). https://doi.org/10.1093/acprof:osobl/9780199336715.003.0006 


\section{COMMITMENT AND IMPERSONATION}

Ginges, J., Atran, S., Medin, D., \& Shikaki, K. (2007). Sacred bounds on rational resolution of violent political conflict. Proceedings of the National Academy of Sciences of the United States of America, 104(18), 7357-7360. https://doi.org/10.1073/pnas.0701768104

Ginges, J., Hansen, I., \& Norenzayan, A. (2009). Religion and support for suicide attacks. Psychological Science, 20(2), 224-230. https://doi.org/10.1111/j.1467-9280.2009.02270.x

Goffman, E. (1959). The presentation of self in everyday life. Doubleday Anchor Books.

Graham, J., \& Haidt, J. (2011). Sacred values and evil adversaries: A moral foundations approach. In P. Shaver \& M. Mikulincer (Eds.), The social psychology of morality: Exploring the causes of good and evil. APA Books.

Graham, J., Haidt, J., \& Nosek, B. A. (2009). Liberals and conservatives rely on different sets of moral foundations. Journal of Personality and Social Psychology, 96(5), 1029-1046. https://doi.org/10.1037/a0015141

Greenbaum, R. L., Mawritz, M. B., \& Piccolo, R. F. (2015). When Leaders Fail to "Walk the Talk": Supervisor Undermining and Perceptions of Leader Hypocrisy. Journal of Management, 41(3), 929-956. https://doi.org/10.1177/0149206312442386

Greitemeyer, T. (2010). Whom would you rather help: An acquaintance not responsible for her plight or a responsible sibling? The Journal of Social Psychology, 143(3), 331-340.

https://doi.org/10.1080/00224540309598448

Griskevicius, V., Tybur, J. M., \& Van den Bergh, B. (2010). Going Green to Be Seen: Status, Reputation, and Conspicuous Conservation. Journal of Personality and Social Psychology, 98(3), 392-404. https://doi.org/10.1037/a0017346

Grodekov, N. I. (2010). The Kazakhs and Kirgiz of the Syr-Darya Oblast. Human Relations Area Files.

Grover, S. L., \& Hasel, M. C. (2015). How Leaders Recover (or Not) from Publicized Sex Scandals. Journal of Business Ethics, 129(1), 177-194. https://doi.org/10.1007/s10551-0142146-3

Guadagno, R. E., \& Cialdini, R. B. (2010). Preference for consistency and social influence: A review of current research findings. Social Influence, 5(3), 152-163.

https://doi.org/10.1080/15534510903332378

Gurven, M. (2004). To give and to give not: The behavioral ecology of human food transfers. Behavioral and Brain Sciences, 27(4), 543-583. https://doi.org/10.1017/S0140525X04000123

Gurven, M., Allen-Arave, W., Hill, K., \& Hurtado, M. (2000). "It's a Wonderful Life": Signaling generosity among the Ache of Paraguay. Evolution and Human Behavior, 21(4), 263-282. https://doi.org/S1090513800000325 [pii]

Hadaway, C. K., Marler, P. L., \& Chaves, M. (1993). What the polls don't show: A closer look at U.S. church attendance. American Sociological Review, 58(6), 741-752.

Haidt, J. (2012). The righteous mind: Why good people are divided by politics and religion. Vintage.

Hallpike, C. R. (1972). Konso Of Ethiopia: A study of the values of an East Cushitic people. Clarendon Press.

Harmon-Jones, E., \& Mills, J. (2019). An introduction to cognitive dissonance theory and an overview of current perspectives on the theory. In E. Harmon-Jones (Ed.), Cognitive dissonance: Reexamining a pivotal theory in psychology (2nd ed.) (pp. 3-24). American Psychological Association.

Harris, M. (1978). India's sacred cow. Human Nature, 1(2), 201-210. 


\section{COMMITMENT AND IMPERSONATION}

Hawkes, K., \& Bird, R. B. (2002). Showing Off, Handicap Signaling, and the Evolution of Men's Work. Evolutionary Anthropology, 11(2), 58-67. https://doi.org/10.1002/evan.20005

Helmreich, R., \& Collins, B. E. (1968). Studies in forced compliance: Commitment and magnitude of inducement to comply as determinants of opinion change. Journal of Personality and Social Psychology, 10(1), 75-81. https://doi.org/10.1037/h0026282

Henrich, J. (2009). The evolution of costly displays, cooperation and religion: credibility enhancing displays and their implications for cultural evolution. Evolution and Human Behavior, 30(4), 244-260. https://doi.org/10.1016/j.evolhumbehav.2009.03.005

Henrich, J. (2020). The WEIRDest people in the world: How the West became psychologically peculiar and particularly prosperous. Farrar, Straus and Giroux.

Henrich, J., Ensminger, J., Mcelreath, R., Barr, A., Barrett, C., Bolyanatz, A., Cardenas, J. C., Gurven, M., Gwako, E., Henrich, N., Lesorogol, C., Marlowe, F., Tracer, D., \& Ziker, J. (2010). Markets, religion, community size, and the evolution of fairness and punishment. Science, 327, 1480-1484. https://doi.org/10.1126/science.1182238

Henrich, J., Heine, S. J., \& Norenzayan, A. (2010). The weirdest people in the world? Behavioral and Brain Sciences, 33(2-3), 61-83; discussion 83-135. https://doi.org/10.1017/S0140525X0999152X

Henry, J. (1941). Jungle people: A Kaingang tribe of the highlands of Brazil. Locust Valley.

Herzog, H. A., \& Golden, L. L. (2009). Moral emotions and social activism: The case of animal rights. Journal of Social Issues, 65(3), 485-498. https://doi.org/10.1111/j.15404560.2009.01610.x

Hoffman, H. S., \& Carver, C. S. (1984). Political waffling: Its effects on the evaluations of observers. Journal of Applied Social Psychology, 14(4), 375-385. https://doi.org/10.1111/j.1559-1816.1984.tb02245.x

Hoffman, M., Hilbe, C., \& Nowak, M. A. (2018). The signal-burying game can explain why we obscure positive traits and good deeds. Nature Human Behaviour, 2(6), 397-404. https://doi.org/10.1038/s41562-018-0354-z

Hoffman, M., Yoeli, E., \& Nowak, M. A. (2015). Cooperate without looking: Why we care what people think and not just what they do. Proceedings of the National Academy of Sciences, 112(6), 1727-1732. https://doi.org/10.1073/pnas.1417904112

Hummel, P. (2010). Flip-flopping from primaries to general elections. Journal of Public Economics, 94(11-12), 1020-1027. https://doi.org/10.1016/j.jpubeco.2010.08.006

Ibhawoh, B. (2017). Dictators and Dissidents. In Human rights in Africa (pp. 173-220). Cambridge University Press. https://doi.org/10.1017/9781139060950.007

James, W. (1891). The moral philosopher and the moral life. International Journal of Ethics, 1(3), 330-354.

John Kerry, flip-flopper? (2004, March 25). The Economist.

Jordan, J. J., Hoffman, M., Nowak, M. A., \& Rand, D. G. (2016). Uncalculating cooperation is used to signal trustworthiness. Proceedings of the National Academy of Science, 113(31), 86588663. https://doi.org/10.1017/CBO9781107415324.004

Jordan, J. J., Sommers, R., Bloom, P., \& Rand, D. G. (2017). Why do we hate hypocrites? Evidence for a theory of false signaling. Psychological Science, 28(3), 356-368. https://doi.org/10.1177/0956797616685771

Kalmijn, M. (2005). Attitude alignment in marriage and cohabitation: The case of sex-role attitudes. Personal Relationships, 12(4), 521-535. https://doi.org/10.1111/j.1475- 


\section{COMMITMENT AND IMPERSONATION}

6811.2005.00129.x

Kannan-Narasimhan, R., \& Lawrence, B. S. (2012). Behavioral integrity: How leader referents and trust matter to workplace outcomes. Journal of Business Ethics, 111(2), 165-178. https://doi.org/10.1007/s10551-011-1199-9

Kartik, N., \& McAfee, R. P. (2007). Signaling character in electoral competition. American Economic Review, 97(3), 852-870. https://doi.org/10.1257/aer.97.3.852

Kaufmann, G. (2013, May 10). This week in poverty: Twelve things you can do to fight poverty now. , The Nation.

Khan, U., \& Dhar, R. (2006). Licensing effect in consumer choice. Journal of Marketing Research, 43(2), 259-266. https://doi.org/10.1509/jmkr.43.2.259

Kim, M., Park, B. K., \& Young, L. (2020). The Psychology of Motivated versus Rational Impression Updating. Trends in Cognitive Sciences, 24(2), 101-111. https://doi.org/10.1016/j.tics.2019.12.001

Klonsky, E. D., May, A. M., \& Saffer, B. Y. (2016). Suicide, suicide attempts, and suicidal ideation. Annual Review of Clinical Psychology, 12(1), 307-330. https://doi.org/10.1146/annurev-clinpsy-021815-093204

Kohlberg, L. (1981). The philosophy of moral development: Moral stages and the idea of justice. Harper \& Row.

Kraft-Todd, G., Yoeli, E., Bhanot, S., \& Rand, D. (2015). Promoting cooperation in the field. Current Opinion in Behavioral Sciences, 3, 96-101. https://doi.org/10.1016/j.cobeha.2015.02.006

Kreps, D. M., \& Wilson, R. (1982). Reputation and imperfect information. Journal of Economic Theory, 27(2), 253-279. https://doi.org/10.1016/0022-0531(82)90030-8

Kreps, T. A., Laurin, K., \& Merritt, A. C. (2017). Hypocritical flip-flop, or couragenous evolution? When leaders change their moral minds. Journal of Personality and Social Psychology, 113(5), 730-752. https://doi.org/10.1037/pspi0000103.supp

Krupp, D. B., Debruine, L. M., \& Barclay, P. (2008). A cue of kinship promotes cooperation for the public good. Evolution and Human Behavior, 29(1), 49-55. https://doi.org/10.1016/j.evolhumbehav.2007.08.002

Kujala, A., \& Danielsbacka, M. (2019). Moral obligations in early modern Japan. In Reciprocity in buman societies (pp. 51-57). Palgrave Macmillan.

Lammers, J., Galinsky, A. D., Dubois, D., \& Rucker, D. D. (2015). Power and morality. Current Opinion in Psychology, 6, 15-19. https://doi.org/10.1016/j.copsyc.2015.03.018

Lammers, J., Stapel, D. A., \& Galinsky, A. D. (2010). Power increases hypocrisy: Moralizing in reasoning, immorality in behavior. Psychological Science, 21(5), 737-744. https://doi.org/10.1177/0956797610368810

Lammers, J., Stoker, J. I., Jordan, J., Pollmann, M., \& Stapel, D. A. (2011). Power increases infidelity among men and women. Psychological Science, 22(9), 1191-1197. https://doi.org/10.1177/0956797611416252

Lankford, A. (2014). Précis of The myth of martyrdom: What really drives suicide bombers, rampage shooters, and other self-destructive killers. Behavioral and Brain Sciences, 37(4), 351-362. https://doi.org/10.1017/S0140525X13001581

Lecky, P. (1945). Self-consistency: A theory of personality. Island Press.

Linder, D. E., Cooper, J., \& Jones, E. E. (1967). Decision freedom as a determinant of the role of incentive magnitude in attitude change. Journal of Personality and Social Psychology, 6(3), 


\section{COMMITMENT AND IMPERSONATION}

245-254. https://doi.org/10.1037/h0021220

Lingel, G. (2018, October 22). Animal rights activists: What are they $E^{2}$ what do they do. Sentient Media. https://sentientmedia.org/animal-rights-activists/

Lyu, S. O. (2016). Travel selfies on social media as objectified self-presentation. Tourism Management, 54, 185-195. https://doi.org/10.1016/j.tourman.2015.11.001

Maestripieri, D., Henry, A., \& Nickels, N. (2017). Explaining financial and prosocial biases in favor of the attractive people: Interdisciplinary perspectives from economics, social psychology, and evolutionary psychology. Behavioral and Brain Sciences, 40, e19, 1-16.

Mailath, G. J., \& Samuelson, L. (2006). Repeated games and reputations: Long-run relationships. Oxford University Press.

Malkis, F. S., Kalle, R. J., \& Tedeschi, J. T. (1982). Attitudinal politics in the forced compliance situation. The Journal of Social Psychology, 117, 79-91.

Malle, B. F. (2011). Attribution Theories: How People Make Sense of Behavior. In D. Chadee (Ed.), Theories in Social Psychology. Wiley-Blackwell.

Marietta, M. (2008). From my cold, dead hands: Democratic consequences of sacred rhetoric. Journal of Politics, 70(3), 767-779. https://doi.org/10.1017/S0022381608080742

Marshall, L. (1962). !Kung Bushman religious beliefs. Africa, 32(3), 221-252.

Maslow, A. H. (1954). Motivation and personality. Harper \& Brothers.

McCaul, K. D., Ployhart, R. E., Hinsz, V. B., \& McCaul, H. S. (1995). Appraisals of a Consistent Versus a Similar Politician: Voter Preferences and Intuitive Judgments. Journal of Personality and Social Psychology, 68(2), 292-299. https://doi.org/10.1037/00223514.68.2.292

McCloskey, D. N. (2016). Bourgeois equality: How ideas, not capital or institutions, enriched the world. University of Chicago Press.

McClosky, H., \& Brill, A. (1983). Dimensions of tolerance: What Americans believe about civil liberties. Russell Sage Foundation.

McCullough, M. E., Kurzban, R., \& Tabak, B. A. (2013). Cognitive systems for revenge and forgiveness. Behavioral and Brain Sciences, 1-58. https://doi.org/10.1017/S0140525X11002160

McGrath, A. (2017). Dealing with dissonance: A review of cognitive dissonance reduction. Social and Personality Psychology Compass, 11(12), 1-17. https://doi.org/10.1111/spc3.12362

McGrath, M. C. (1922). A study of the moral development of children. Psychological Monographs, 32(2).

McGraw, A. P., Davis, D. F., Scott, S. E., \& Tetlock, P. E. (2016). The price of not putting a price on love. Judgment and Decision Making, 11(1), 40-47.

McGraw, A. P., Schwartz, J. A., \& Tetlock, P. E. (2012). From the Commercial to the Communal: Reframing Taboo Trade-offs in Religious and Pharmaceutical Marketing. Journal of Consumer Research, 39(1), 157-173. https://doi.org/10.1086/662070

McGraw, A. P., \& Tetlock, P. E. (2005). Taboo trade-offs, relational framing, and the acceptability of exchanges. Journal of Consumer Psychology, 15(1), 2-15. https://doi.org/10.1207/s15327663jcp1501_2

McGraw, K. M. (1998). Manipulating public opinion with moral justification. The Annals of the American Academy of Political and Social Science, 560, 129-142.

McGraw, K. M., Best, S., \& Timpone, R. (1995). "What They Say or What They Do?" The Impact of Elite Explanation and Policy Outcomes on Public Opinion. American Journal of 


\section{COMMITMENT AND IMPERSONATION}

Political Science, 39(1), 53. https://doi.org/10.2307/2111757

Mei, Y.-P. (1973). The ethical and political works of Motse. Hyperion. https://ctext.org/mozi

Meijers, M. (2014). On justifying eco-unfriendly behaviors. University of Amsterdam.

Mercier, H. (2020). Not born yesterday: The science of who we trust and what we believe. Princeton University Press.

Mercier, H., \& Sperber, D. (2011). Why do humans reason? Arguments for an argumentative theory. Behavioral and Brain Sciences, 34(2), 57-74; discussion 74-111.

https://doi.org/10.1017/S0140525X10000968

Metge, J. (1995). New growth from old: The Whanau in the modern world. Victoria University Press.

Milinski, M. (2016). Reputation, a universal currency for human social interactions. Philosophical Transactions of the Royal Society B, Biological Sciences, 371, 20150100. https://doi.org/10.1098/rstb.2015.0100

Monin, B., \& Miller, D. T. (2001). Moral credentials and the expression of prejudice. Journal of Personality and Social Psychology, 81(1), 33-43. https://doi.org/10.1037/0022-3514.81.1.33

Mukherjea, C. (1962). The Santals. A. Mukherjee \& Co., Private Ltd.

Mullen, E., \& Monin, B. (2016). Consistency Versus Licensing Effects of Past Moral Behavior. Annual Review of Psychology, 67(1), 363-385. https://doi.org/10.1146/annurev-psych010213-115120

Muthukrishna, M., \& Henrich, J. (2019). A problem in theory. Nature Human Behaviour, 3, 221-229. https://doi.org/10.1038/s41562-018-0522-1

Nahmod, S. H. (1991). The sacred flag and the first amendment. Indiana Law Journal, 66, 511548.

Naughton, J. M. (1976, May 4). Ford says Carter does a “flip-flop.” The New York Times, 1.

Newcomb, T. M. (1957). Personality and social change: Attitude formation in a study community. Holt, Rinehart, and Winston.

Norenzayan, A. (2013). Big gods: How religion transformed cooperation and conflict. Princeton University Press.

Norenzayan, A., Shariff, A. F., Gervais, W. M., Willard, A. K., McNamara, R. A., Slingerland, E., \& Henrich, J. (2016). The cultural evolution of prosocial religions. Behavioral and Brain Sciences, 39, e1. https://doi.org/10.1017/S0140525X14001356

Nowak, M. A., \& Sigmund, K. (2005). Evolution of indirect reciprocity. Nature, 437(October), 1291-1298. https://doi.org/10.1038/nature04131

Oberg, S. A. K., Christie, G. J., \& Tata, M. S. (2011). Problem gamblers exhibit reward hypersensitivity in medial frontal cortex during gambling. Neuropsychologia, 49(13), 37683775. https://doi.org/10.1016/j.neuropsychologia.2011.09.037

Osbaldiston, R., \& Schott, J. P. (2012). Environmental sustainability and behavioral science: Meta-analysis of proenvironmental behavior experiments. Environment and Behavior, 44(2), 257-299. https://doi.org/10.1177/0013916511402673

Palanski, M. E., \& Yammarino, F. J. (2007). Integrity and Leadership:. Clearing the Conceptual Confusion. European Management Journal, 25(3), 171-184.

https://doi.org/10.1016/j.emj.2007.04.006

Pascarella, E. T., \& Terenzini, P. T. (1991). How college affects students: Findings and insights from twenty years of research. Jossey-Bass Publishers.

Peletz, M. G. (1988). Share of the harvest: Kinship, property, and social history among the Malays of 


\section{COMMITMENT AND IMPERSONATION}

Rembau. University of California Press.

Peoples, H. C., \& Marlowe, F. W. (2012). Subsistence and the evolution of religion. Human Nature, 23(3), 253-269. https://doi.org/10.1007/s12110-012-9148-6

Pettigrew, T. F. (1979). The ultimate attribution error: Extending Allport's cognitive analysis of prejudice. Personality and Social Psychology Bulletin, 5(4), 461-476.

https://doi.org/10.1177/07399863870092005

Pew Research Center. (2015). America's changing religious landscape. https://www.pewforum.org/2015/05/12/americas-changing-religious-landscape/

Pew Research Center. (2017). The changing global religious landscape.

Phillips, J., \& Cushman, F. (2017). Morality constrains the default representation of what is possible. Proceedings of the National Academy of Sciences of the United States of America, 114(18), 4649-4654. https://doi.org/10.1073/pnas.1619717114

Piaget, J. (1932). The Moral Judgement of the Child. Routledge \& Kegan Paul.

Piff, P. K., Stancato, D. M., Côté, S., Mendoza-Denton, R., \& Keltner, D. (2012). Higher social class predicts increased unethical behavior. Proceedings of the National Academy of Sciences of the United States of America, 109(11), 4086-4091. https://doi.org/10.1073/pnas.1118373109

Pinker, S. (1997). How the mind works. W. W. Norton \& Company.

Pinker, S. (2011). The better angels of our nature: Why violence has declined. Penguin.

Pinker, S. (2012). The false allure of group selection. Edge. https://www.edge.org/conversation/steven_pinker-the-false-allure-of-group-selection

Pisor, A. C., \& Gurven, M. (2018). When to diversify, and with whom? Choosing partners among out-group strangers in lowland Bolivia. Evolution and Human Behavior, 39(1), 3039. https://doi.org/10.1016/j.evolhumbehav.2017.09.003

Posner, E. A. (1998). The strategic basis of principled behavior: A critique of the incommensurability thesis. University of Pennsylvania Law Review, 146(5), 1185-1214.

Posner, E. A. (2000). Law and social norms. Harvard University Press.

President's Committee on Civil Rights. (1947). To secure these rights. Government Printing. https://www.trumanlibrary.gov/library/to-secure-these-rights

Priolo, D., Pelt, A., Bauzel, R. S., Rubens, L., Voisin, D., \& Fointiat, V. (2019). Three Decades of Research on Induced Hypocrisy: A Meta-Analysis. Personality and Social Psychology Bulletin, 45(12), 1681-1701. https://doi.org/10.1177/0146167219841621

Prottas, D. J. (2008). Perceived behavioral integrity: Relationships with employee attitudes, wellbeing, and absenteeism. Journal of Business Ethics, 81(2), 313-322. https://doi.org/10.1007/s10551-007-9496-z

Purzycki, B. G., Willard, A. K., Kundtov, E., Apicella, C., Atkinson, Q., Bolyanatz, A., Cohen, E., Handley, C., Henrich, J., Lang, M., Lesorogol, C., McNamara, R. A., Moya, C., Norenzayan, A., Placek, C., Soler, M., Weigel, J., Xygalatas, D., \& Ross, C. T. (2020). The Moralization Bias of Gods 'Minds : A Cross-Cultural Test.

Rai, T. S., \& Fiske, A. P. (2011). Moral psychology is relationship regulation: Moral motives for unity, hierarchy, equality, and proportionality. Psychological Review, 118(1), 57-75. https://doi.org/10.1037/a0021867

Reichel-Dolmatoff, G. (1976). Training for the priesthood among the Kogi of Colombia. In Enculturation in Latin America: An anthology (pp. 265-288). UCLA Latin American Center Publications. 


\section{COMMITMENT AND IMPERSONATION}

Reid, C. A., Green, J. D., \& Davis, J. L. (2018). Attitude alignment increases trust, respect, and perceived reasoning ability to produce attraction. Personal Relationships, 25(2), 171-189. https://doi.org/10.1111/pere.12237

Roes, F., \& Raymond, M. (2003). Belief in moralizing gods. Evolution and Human Behavior, 24(2), 126-135. https://doi.org/10.1007/s12110-014-9214-3

Rotella, A., Jung, J., Chinn, C., \& Barclay, P. (n.d.). Observation and moral ambiguity matter: $A$ meta-analysis on moral licensing.

Roth, A. E. (2007). Repugnance as a Constraint on Markets. Journal of Economic Perspectives, 21(3), 37-58. https://doi.org/10.1257/jep.21.3.37

Rudolph, U., Roesch, S. C., Greitemeyer, T., \&Weiner, B. (2004). A meta-analytic review of help giving and aggression from an attributional perspective: Contributions to a general theory of motivation. Cognition and Emotion, 18(6), 815-848. https://doi.org/10.1080/02699930341000248

Russell, B. (1972). A history of Western philosophy. Simon \& Schuster.

Ryan, T. J. (2017). No compromise: Political consequences of moralized attitudes. American Journal of Political Science, 61(2), 409-423. https://doi.org/10.1111/ajps.12248

Sacco, D. F., Brown, M., Lustgraaf, C. J. N., \& Hugenberg, K. (2017). The adaptive utility of deontology: Deontological moral decision-making fosters perceptions of trust and likeability. Evolutionary Psychological Science, 3(2), 125-132. https://doi.org/10.1007/s40806-016-0080-6

Sachdeva, S., \& Medin, D. (2009). Group identity salience in sacred value based cultural conflict: An examination of the Hindu-Muslim identities in the Kashmir and Babri mosque issues. Proceedings of the 31st Annual Conference of the Cognitive Science Society, 3111-3114. http://csjarchive.cogsci.rpi.edu/Proceedings/2009/papers/677/paper677.pdf

Sageman, M. (2008). Leaderless Jihad: Terror networks in the twenty-first century. University of Pennsylvania Press. https://doi.org/10.1093/police/pan057

Sakai, H. (1981). Induced compliance and opinion change. Japanese Psychological Research, 23(1), $1-8$.

Saner, E. (2019, May 22). Could you give up flying? Meet the no-plane pioneers. The Guardian. https://www.theguardian.com/travel/2019/may/22/could-you-give-up-flying-meet-the-noplane-pioneers

Scott-Phillips, T. C., Dickins, T. E., \& West, S. a. (2011). Evolutionary theory and the ultimate-proximate distinction in the human behavioral sciences. Perspectives on Psychological Science, 6(1), 38-47. https://doi.org/10.1177/1745691610393528

Scott, M. B., \& Lyman, S. M. (1968). Accounts. American Sociological Review, 33(1), 46-62.

Sedikides, C., \& Gebauer, J. E. (2010). Religiosity as self-enhancement: A meta-analysis of the relation between socially desirable responding and religiosity. Personality and Social Psychology Review, 14(1), 17-36. https://doi.org/10.1177/1088868309351002

Shaw, A. (2016). Fairness: What it isn't, what it is, and what it might be for. In D. C. Geary \& D. B. Berch (Eds.), Evolutionary Perspectives on Child Development and Education. Springer. https://doi.org/10.1007/978-3-319-29986-0

Shaw, A., Montinari, N., Piovesan, M., Olson, K. R., Gino, F., \& Norton, M. I. (2014). Children develop a veil of fairness. Journal of Experimental Psychology: General, 143(1), 363375. https://doi.org/10.1037/a0031247

Shultz, T. R., Léveillé, E., \& Lepper, M. R. (2011). Free choice and cognitive dissonance 


\section{COMMITMENT AND IMPERSONATION}

revisited: Choosing "lesser evils" versus "greater goods." Personality and Social Psychology Bulletin, 25(1), 40-48.

Sigelman, L., \& Sigelman, C. K. (1986). Shattered expectations: Public responses to "out-ofcharacter" presidential actions. Political Behavior, 8(3), 262-286. https://doi.org/10.1007/BF01002101

Silk, J. B. (2003). Cooperation without counting. In P. Hammerstein (Ed.), Genetic and Cultural Evolution of Cooperation. The MIT Press. https://doi.org/10.7551/mitpress/3232.003.0005

Simons, T., Leroy, H., Collewaert, V., \& Masschelein, S. (2015). How Leader Alignment of Words and Deeds Affects Followers: A Meta-analysis of Behavioral Integrity Research. Journal of Business Ethics, 132(4), 831-844. https://doi.org/10.1007/s10551-014-2332-3

Singer, P. (2002). Animal liberation. Ecco.

Singh, M. (n.d.). Magic, explanations, and evil: On the origins and design of witches and sorcerers. Current Anthropology.

Singh, M., Kaptchuk, T. J., \& Henrich, J. (2021). Small gods, rituals, and cooperation: The Mentawai water spirit Sikameinan. Evolution and Human Behavior, 42(1), 61-72. https://doi.org/10.1016/j.evolhumbehav.2020.07.008

Singh, M., Wrangham, R. W., \& Glowacki, L. (2017). Self-interest and the design of rules. Human Nature, 28, 457-480. https://doi.org/10.1007/s12110-017-9298-7

Siziba, S., \& Bulte, E. (2012). Does market participation promote generalized trust? Experimental evidence from Southern Africa. Economics Letters, 117(1), 156-160. https://doi.org/10.1016/j.econlet.2012.05.003

Skrentny, J. D. (1998). The effect of the Cold War on African-American civil rights: America and the world audience, 1945-1968. Theory and Society, 27(2), 237-285.

Snarey, J. R. (1985). Cross-cultural universality of social-moral development: A critical review of Kohlbergian research. Psychological Bulletin, 97(3), 411-411. https://doi.org/10.1037/h0090442

Stanford, P. K. (2018). The difference between ice cream and Nazis: Moral externalization and the evolution of human cooperation. Behavioral and Brain Sciences, 41, e95. https://doi.org/10.1017/S0140525X17001911

Stoller, P. (1989). Fusion of the worlds: An ethnography of possession among the Songhay of Niger. University of Chicago Press.

Stone, J., Aronson, E., Crain, A. L., Winslow, M. P., \& Fried, C. B. (1994). Inducing hypocrisy as a means of encouraging young adults to use condoms. Personality and Social Psychology Bulletin, 20(1), 116-128.

Stone, J., Cooper, J., Wiegand, A. W., \& Aronson, E. (1997). When Exemplification Fails: Hypocrisy and the Motive for Self-Integrity. Journal of Personality and Social Psychology, 72(1), 54-65. https://doi.org/10.1037/0022-3514.72.1.54

Stone, J., \& Fernandez, N. C. (2008a). How behavior shapes attitudes: Cognitive dissonance processes. In W. D. Crano \& R. Prislin (Eds.), Attitudes and attitude change (pp. 313-334). Psychology Press.

Stone, J., \& Fernandez, N. C. (2008b). To practice what we preach: The use of hypocrisy and cognitive dissonance to motivate behavior change. Social and Personality Psychology Compass, 2, 1024-1051.

Suh, E. M. (2002). Culture, identity consistency, and subjective well-being. Journal of Personality and Social Psychology, 83(6), 1378-1391. https://doi.org/10.1037/0022-3514.83.6.1378 


\section{COMMITMENT AND IMPERSONATION}

Sunstein, C. R. (1994). Incommensurability and valuation in law. Michigan Law Review, 92(4), 779. https://doi.org/10.2307/1289693

Sunstein, C. R. (2005). Moral heuristics. Behavioral and Brain Sciences, 28, 531-573.

Swann, W. B., \& Read, S. J. (1981). Self-verification processes: How we sustain our selfconceptions. Journal of Experimental Social Psychology, 17(4), 351-372. https://doi.org/10.1016/0022-1031(81)90043-3

Swanson, G. E. (1964). The birth of the gods: The origin of primitive beliefs. The University of Michigan Press.

Syme, K. L., Garfield, Z. H., \& Hagen, E. H. (2016). Testing the bargaining vs. inclusive fitness models of suicidal behavior against the ethnographic record. Evolution and Human Behavior, 37(3), 179-192. https://doi.org/10.1016/j.evolhumbehav.2015.10.005

Tan, J. H. W., \& Vogel, C. (2008). Religion and trust: An experimental study. Journal of Economic Psychology, 29(6), 832-848. https://doi.org/10.1016/j.joep.2008.03.002

Tavits, M. (2007). Principle vs. pragmatism: Policy shifts and political competition. American Journal of Political Science, 51(1), 151-165. https://doi.org/10.1111/j.15405907.2007.00243.x

Tedeschi, J. T., \& Rosenfeld, P. (1981). Impression management theory and the forced compliance situation. In J. T. Tedeschi (Ed.), Impression management theory and social psychological research. Academic Press.

Tedeschi, J. T., Schlenker, B. R., \& Bonoma, T. V. (1971). Cognitive dissonance: Private ratiocination or public spectacle? American Psychologist, 26(8), 685-695. https://doi.org/10.1037/h0032110

Tetlock, P. E. (2000). Coping with Trade-Offs: Psychological Constraints and Political Implications. https://doi.org/10.1017/cbo9780511805813.011

Tetlock, P. E. (2003). Thinking the unthinkable: sacred values and taboo cognitions. Trends in Cognitive Sciences, 7(7), 320-324. https://doi.org/10.1016/S1364-6613(03)00135-9

Tetlock, P. E., Kristel, O. V, Elson, S. B., Green, M. C., \& Lerner, J. S. (2000). The psychology of the unthinkable: Taboo trade-offs, forbidden base rates, and heretical counterfactuals. Journal of Personality and Social Psychology, 78(5), 853-870. https://doi.org/10.1037//0022-3514.78.5.853

Tetlock, P. E., Mellers, B. A., \& Scoblic, J. P. (2020). Sacred versus pseudo-sacred values: How people cope with taboo trade-offs. The American Economic Review, 107(5), 96-99.

The Satanic Temple. (2020). Tenets - The Satanic Temple. https://thesatanictemple.com/pages/tenets

The Vegan Society. (2020). Why go vegan? https://www.vegansociety.com/go-vegan/why-govegan

Thompson, L. L., \& Gonzalez, R. (1997). Environmental disputes: Competition for scarce resources and clashing of values. In M. H. Bazerman, D. M. Messick, A. E. Tenbrunsel, \& K. A. Wade-Benzoni (Eds.), Environment, ethics, and behavior: The psychology of environmental valuation and degradation (pp. 75-104). New Lexington Press.

Tomz, M., \& Van Houweling, R. P. (2010). Candidate repositioning.

Tomz, M., \& Van Houweling, R. P. (2016). Political repositioning: A conjoint analysis.

Trivers, R. (1971). The evolution of reciprocal altruism. Quarterly Review of Biology, 46, 35-57. http://www.jstor.org/stable/10.2307/2822435

Tu, Q., \& Bulte, E. (2010). Trust, Market Participation and Economic Outcomes: Evidence 


\section{COMMITMENT AND IMPERSONATION}

from Rural China. World Development, 38(8), 1179-1190.

https://doi.org/10.1016/j.worlddev.2009.12.014

UN General Assembly. (1948). Universal declaration of human rights. https://www.ohchr.org/EN/UDHR/Documents/UDHR_Translations/eng.pdf

Vallerand, R. J. (2015). The psychology of passion: A dualistic model. Oxford University Press. https://doi.org/10.1093/acprof:oso/9780199777600.001.0001

Vallerand, R. J., Mageau, G. A., Ratelle, C., Léonard, M., Blanchard, C., Koestner, R., Gagné, M., \& Marsolais, J. (2003). Les passions de l'âme: On obsessive and harmonious passion. Journal of Personality and Social Psychology, 85(4), 756-767. https://doi.org/10.1037/00223514.85.4.756

Van Norden, B. W. (2007). Virtue ethics and consequentialism in early Chinese philosophy. Cambridge University Press.

Van Zant, A. B., \& Moore, D. A. (2015). Leaders' Use of Moral Justifications Increases Policy Support. Psychological Science, 26(6), 934-943. https://doi.org/10.1177/0956797615572909

Villanueva, G. (2016). 'The Bible' of the animal movement: Peter Singer and animal liberation, 1970-1976. History Australia, 13(3), 399-414. https://doi.org/10.1080/14490854.2016.1202372

Vogelgesang, G. R., Leroy, H., \& Avolio, B. J. (2013). The mediating effects of leader integrity with transparency in communication and work engagement/performance. Leadership Quarterly, 24(3), 405-413. https://doi.org/10.1016/j.leaqua.2013.01.004

Voisin, D., Stone, J., \& Becker, M. (2013). The Impact of the antitobacco norm on the selected mode of cognitive dissonance reduction. Journal of Applied Social Psychology, 43(1), 57-67. https://doi.org/10.1111/j.1559-1816.2012.00981.x

Volokh, E. (2003). The Mechanisms of the Slippery Slope. Harvard Law Review, 116(4), 10261137. https://doi.org/10.2307/1342743

von Hippel, W., \& Trivers, R. (2011). The evolution and psychology of self-deception. Behavioral and Brain Sciences, 34(1), 1-16; discussion 16-56. https://doi.org/10.1017/S0140525X10001354

Wallace, E., \& Hoebel, E. A. (1952). The Comanches: Lords of the south Plains. University of Oklahoma Press.

Watts, J., Greenhill, S. J., Atkinson, Q. D., Currie, T. E., Bulbulia, J., \& Gray, R. D. (2015). Broad supernatural punishment but not moralizing high gods precede the evolution of political complexity in Austronesia. Proceedings of the Royal Society B, 282, 20142556.

Wilbert, J. (1972). Survivors of Eldorado: Four Indian cultures of South America. Praeger Publishers.

Wilkinson, R. J. (1925). Malay literature: Malay proverbs on Malay character. J. E. Wallace at the F. M. S. Government Press.

Wilkinson, S., \& Garrard, E. (1996). Bodily integrity and the sale of human organs. Journal of Medical Ethics, 22(6), 334-339. https://doi.org/10.1136/jme.22.6.334

Winek, J. L., \& Craven, P. A. (2003). Healing rituals for couples recovering from adultery. Contemporary Family Therapy, 25(3), 249-266. https://doi.org/10.1023/A:1024518719817

Wood, Jr., J. E. (1989). Making a nation's flag a sacred symbol. Journal of Church and State, 31(3), 375-380.

Wright, R. (2009). The evolution of god. Little, Brown and Company.

Yoeli, E., Hoffman, M., Rand, D. G., \& Nowak, M. A. (2013). Powering up with indirect 


\section{COMMITMENT AND IMPERSONATION}

reciprocity in a large-scale field experiment. Proceedings of the National Academy of Sciences of the United States of America, 110(SUPPL2), 10424-10429.

https://doi.org/10.1073/pnas.1301210110

Zanna, M. P., \& Cooper, J. (1974). Dissonance and the pill: An attribution approach to studying the arousal properties of dissonance. Journal of Personality and Social Psychology, 29(5), 703-709. https://doi.org/10.1037/h0036651

Zanna, M. P., \& Sande, G. N. (1987). The effects of collective actions on the attitudes of individual group members: A dissonanc analysis. In M. P. Zanna, J. M. Olson, \& C. P. Herman (Eds.), Social influence: The Ontario Symposium (pp. 151-163). Lawrence Erlbaum Associates.

Zlatev, J. J. (2019). I may not agree with you, but I trust you: Caring about social issues signals integrity. Psychological Science, 30(6), 880-892. https://doi.org/10.1177/0956797619837948 